\title{
Uncertainties in model predictions of nitrogen fluxes from agro-ecosystems in Europe
}

\author{
J. Kros ${ }^{1}$, G. B. M. Heuvelink ${ }^{2}$, G. J. Reinds ${ }^{1}$, J. P. Lesschen ${ }^{1}$, V. Ioannidi ${ }^{1}$, and W. De Vries ${ }^{1,3}$ \\ ${ }^{1}$ Alterra, part of Wageningen UR, P.O. Box 47, 6700 AA Wageningen, The Netherlands \\ ${ }^{2}$ Land Dynamics Group, Wageningen University, P.O. Box 47, 6700 AA Wageningen, The Netherlands \\ ${ }^{3}$ Environmental Systems Analysis Group, Wageningen University, P.O. Box 47, 6700 AA Wageningen, The Netherlands
}

Correspondence to: J. Kros (hans.kros@wur.nl)

Received: 26 April 2012 - Published in Biogeosciences Discuss.: 29 May 2012

Revised: 26 September 2012 - Accepted: 24 October 2012 - Published: 20 November 2012

\begin{abstract}
To assess the responses of nitrogen and greenhouse gas emissions to pan-European changes in land cover, land management and climate, an integrated dynamic model, INTEGRATOR, has been developed. This model includes both simple process-based descriptions and empirical relationships and uses detailed GIS-based environmental and farming data in combination with various downscaling methods. This paper analyses the propagation of uncertainties in model inputs and parameters to outputs of INTEGRATOR, using a Monte Carlo analysis. Uncertain model inputs and parameters were represented by probability distributions, while spatial correlation in these uncertainties was taken into account by assigning correlation coefficients at various spatial scales. The uncertainty propagation was analysed for the emissions of $\mathrm{NH}_{3}, \mathrm{~N}_{2} \mathrm{O}$ and $\mathrm{NO}_{\mathrm{x}}, \mathrm{N}$ leaching to groundwater and $\mathrm{N}$ runoff to surface water for the entire EU27 and for individual countries. Results show large uncertainties for $\mathrm{N}$ leaching and runoff (relative errors of $\sim 19 \%$ for Europe as a whole), and smaller uncertainties for emission of $\mathrm{N}_{2} \mathrm{O}$, $\mathrm{NH}_{3}$ and $\mathrm{NO}_{\mathrm{x}}$ (relative errors of $\sim 12 \%$ ). Uncertainties for Europe as a whole were much smaller compared to uncertainties at country level, because errors partly cancelled out due to spatial aggregation.
\end{abstract}

\section{Introduction}

The nitrogen cycle is of fundamental importance in ecosystem functioning, global change and human health issues. Nitrogen provides a key control of the global carbon cycle through effects on primary production and decomposition.
It is a major determinant of terrestrial and aquatic biodiversity (Dise et al., 2011). It influences particle formation and other chemical production processes in the atmosphere and has major impacts on greenhouse gas (GHG) fluxes via nitrous oxide $\left(\mathrm{N}_{2} \mathrm{O}\right)$ and indirectly carbon dioxide $\left(\mathrm{CO}_{2}\right)$ and methane $\left(\mathrm{CH}_{4}\right)$ (Butterbach-Bahl et al., 2011; De Vries et al., 2011a).

Several estimates have been made of European-wide land nitrogen $(\mathrm{N})$ budgets, including emissions of ammonia $\left(\mathrm{NH}_{3}\right)$, nitrogen oxides $\left(\mathrm{NO}_{\mathrm{x}}\right)$ nitrous oxide $\left(\mathrm{N}_{2} \mathrm{O}\right)$ and di-nitrogen $\left(\mathrm{N}_{2}\right)$, and the leaching and runoff of $\mathrm{N}$ (mainly nitrate, $\mathrm{NO}_{3}{ }^{-}$) to ground- and surface waters (Stohl et al., 1996; Bouwman et al., 1997; Mosier et al., 1998; Freibauer, 2003; Van Drecht et al., 2003). These estimates were based on coarse or generic data, because much of the information required for a detailed assessment of $\mathrm{N}$ emissions from agriculture is not included in current European databases (Leip, 2004). De Vries et al. (2011b) disclosed these detailed data, which are used in the model INTEGRATOR for Europeanwide $\mathrm{N}$ and GHG emissions estimates. The model was developed within the framework of the European Integrated Project NitroEurope (Sutton et al., 2007) to model the response of reactive nitrogen $(\mathrm{Nr})$ and $\mathrm{GHG}$ emissions due to land-use changes (De Vries et al., 2011b) and the effect of mitigation measures (Kros et al., 2011).

Until now, a systematic uncertainty assessment of all $\mathrm{N}$ fluxes from terrestrial systems at large regional scales is lacking almost completely and uncertainties reported in the literature vary widely. One of the few examples is from De Vries et al. (2003), who performed an uncertainty analysis of all major $\mathrm{N}$ flows in the Netherlands. This research, however, 
neglected the uncertainty due to spatial model inputs such as soil type and land use, which also influence the uncertainty in GHG predictions (Mosier et al., 1998; Pihlatie et al., 2004) and spatial correlations between these uncertain model inputs. Most research has been focussed on uncertainties in $\mathrm{N}_{2} \mathrm{O}$ emissions, which have been quantified at field scale (e.g. Lehuger et al., 2009), at landscape scale (e.g. Nol et al., 2010) and at national scale (e.g. Del Grosso et al., 2010). Nol et al. (2010) performed an uncertainty propagation analysis for a Dutch fen meadow landscape using the INITIATOR model, while including uncertain spatial model inputs. They used a Monte Carlo (MC) analysis combined with a novel method for estimating and simulating continuous-numerical and categorical input variables, handling spatial and crosscorrelations. Del Grosso et al. (2010) performed a nationwide uncertainty analysis, using the DAYCENT model combined with an empirical approach, to quantify uncertainties in soil $\mathrm{N}_{2} \mathrm{O}$ emissions from croplands in the USA. Uncertainty assessments have also been done for total atmospheric emissions of $\mathrm{NH}_{3}, \mathrm{~N}_{2} \mathrm{O}$ and $\mathrm{NO}_{\mathrm{x}}$ for various countries, such as the Netherlands (Van Gijlswijk et al., 2004).

Apart from uncertainty assessments that focus on the propagation of model input uncertainty to model outputs, insight in the uncertainty of $\mathrm{N}$ fluxes can also be derived from model inter-comparisons. Results of INTEGRATOR, for example, have been thoroughly compared with the results of other European-wide $\mathrm{N}$ budget models, including $\mathrm{NH}_{3}$, $\mathrm{N}_{2} \mathrm{O}$ and $\mathrm{NO}_{\mathrm{x}}$ emissions and the sum of $\mathrm{N}$ leaching and $\mathrm{N}$ runoff to ground- and surface water (De Vries et al., 2011b). Furthermore, Leip et al. (2011b) provided an overview of European-wide $\mathrm{N}_{2} \mathrm{O}$ estimates based on different empirical and process-based model applications.

The aim of this paper is to analyse how uncertainties in model inputs and parameters propagate to model outputs, focussing on uncertainties in continuous model inputs (e.g. fertilizer use) and model parameters (e.g. excretion factors and emission fractions). We present an MC propagation analysis with INTEGRATOR at the European scale, while taking spatial correlation into account. The considered outputs are $\mathrm{N}_{2} \mathrm{O}, \mathrm{NO}_{\mathrm{x}}$ and $\mathrm{NH}_{3}$ emission, $\mathrm{N}$ leaching to groundwater and $\mathrm{N}$ runoff to surface water for the year 2000 . Uncertainties in climate, land cover and soil type were not included. The study focussed at (i) uncertainty quantification (UQ) of $\mathrm{N}$ fluxes for the entire EU27 and for individual member states, (ii) the identification of the main sources of uncertainty for all $\mathrm{N}$ output variables (uncertainty analysis, UA), and (iii) the quantification of the robustness of the uncertainty assessment (robustness analysis, RA).

\section{Modelling $\mathrm{N}$ fluxes in agriculture at the European scale}

INTEGRATOR uses (i) relatively simple and transparent model calculations based on existing model approaches, and (ii) high-resolution spatially explicit input data. INTEGRATOR includes various sub-models for the prediction of $\mathrm{N}\left(\mathrm{NH}_{3}, \mathrm{NO}_{\mathrm{x}}, \mathrm{N}_{2} \mathrm{O}\right.$ and $\left.\mathrm{N}_{2}\right)$ emissions and $\mathrm{N}$ leaching from (i) housing and manure storage systems and agricultural soils, i.e. an adapted version of the MITERRAEurope model (Velthof et al., 2009; Lesschen et al., 2011), (ii) non-agricultural terrestrial systems, and (iii) an emissiondeposition matrix for $\mathrm{NH}_{3}$ and $\mathrm{NO}_{\mathrm{x}}$, based on the EMEP model (Simpson et al., 2006) to assess interactions between agricultural and non-agricultural land. INTEGRATOR (Fig. 1) calculates the total manure production for each FSSNUTS region, i.e. Farm Structure Survey (FSS) regions which are either at NUTS (Nomenclature of Territorial Units for Statistics) 2 or 3 level (Leip et al., 2008). The manure production is calculated from the animal numbers, available at FSSNUTS level, and the $\mathrm{N}$ excretion per animal category, available at country level. A division is made between excretion of animals in housing systems and grazing animals in pastures, based on data at country level. All manure produced in housing and manure storage systems within an FSSNUTS region, corrected for nutrient losses (gaseous and leaching) in these storage systems, is applied to agricultural land in the same region (no manure transport between regions). Weighing factors for grassland, fodder crops and other crops are used to distribute animal manure, which are country dependent (Velthof et al., 2009).

Fertilizer $\mathrm{N}$ application is based on national fertilizer consumption rates for the year 2000 (FAO, 2010). For each country, the mineral fertilizer is distributed over crops using weighing factors that are based on the $\mathrm{N}$ uptake of the crop (sum of $\mathrm{N}$ in harvested products and $\mathrm{N}$ in crop residues). $\mathrm{N}$ uptake is calculated as the product of yield and $\mathrm{N}$ content, where the $\mathrm{N}$ content depends on the current $\mathrm{N}$ input. The yields of arable crops for each country were derived from FAO statistics on a country basis (FAO, 2010). The $\mathrm{N}$ contents of harvested crop products and the amount of crop residues were derived from the literature (see Velthof et al., 2009).

The emission of gaseous $\mathrm{N}$ compounds $\left(\mathrm{NH}_{3}, \mathrm{~N}_{2} \mathrm{O}\right.$, $\mathrm{NO}$ and $\mathrm{N}_{2}$ ) accounted for in the model includes emission (i) from faeces and urine during storage in housing and manure storage systems, (ii) by grazing animals, (iii) after application of manure and fertilizers to agricultural land and (iv) due to atmospheric deposition, nitrogen fixation and crop residue input (not included for $\mathrm{NH}_{3}$ ). $\mathrm{NH}_{3}, \mathrm{~N}_{2} \mathrm{O}$ and $\mathrm{NO}_{\mathrm{x}}$ emissions from housing/manure storage and grazing are calculated by multiplying the number of animals and excretion rates per animal category by country-specific emission factors based on the GAINS model (Klimont and Brink, 2004). $\mathrm{NH}_{3}$ emissions due to fertilizer and animal manure application are calculated by multiplying the application rates of different animal manures and fertilizers by animal and country-specific (related to application techniques) emission factors based on the GAINS model (Klimont and Brink, 2004). Contrary to MITERRA-Europe, which uses generic 


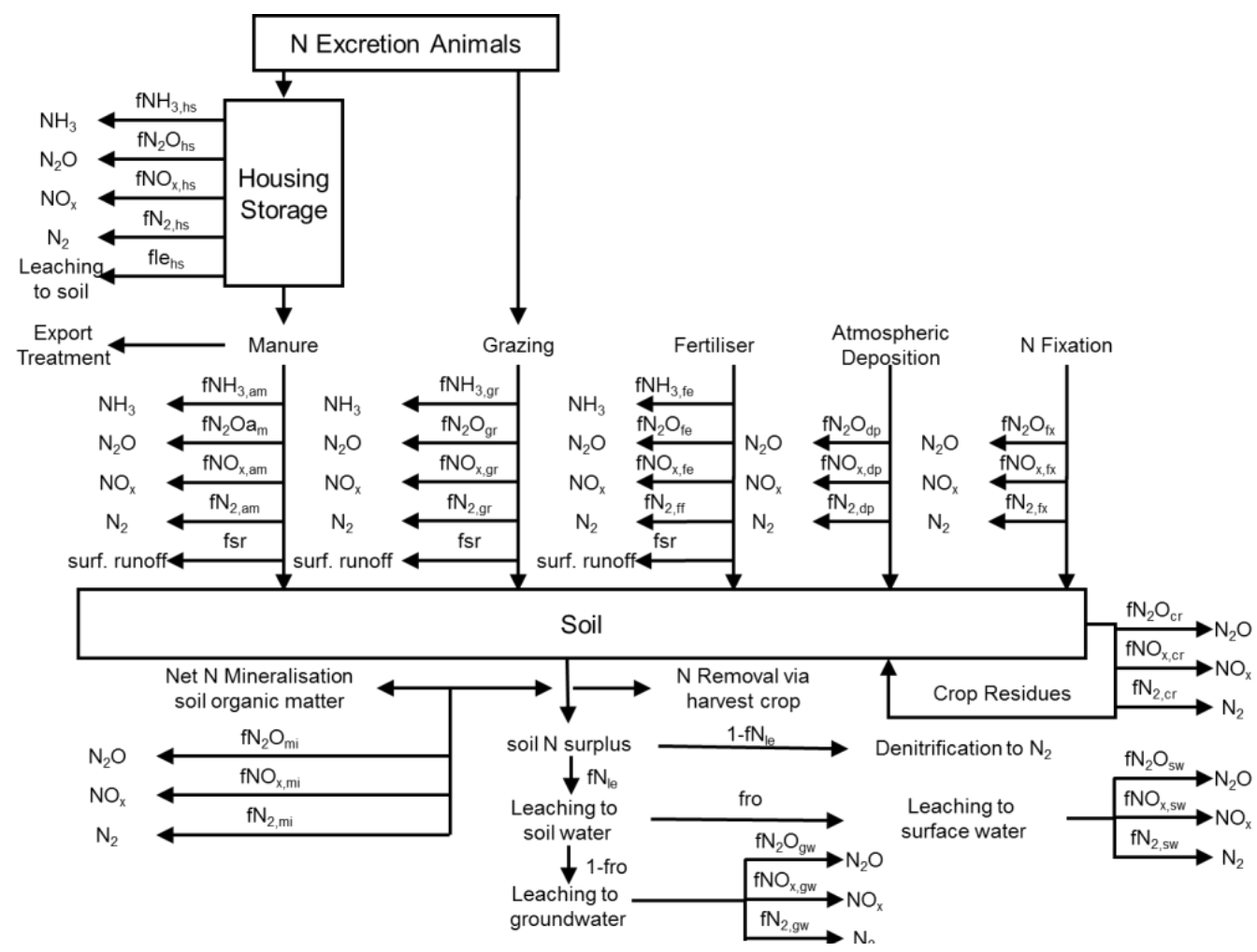

Fig. 1. $\mathrm{N}$ transfer processes included in the agricultural module of INTEGRATOR (the adapted MITERRA-Europe model).

$\mathrm{N}_{2} \mathrm{O}$ emission factors for fertilizer and animal manure application, INTEGRATOR uses soil emission factors that vary with the $\mathrm{N}$ source (three fertilizer types, seven manure types, three crop residue types, mineralized soil organic N, biological $\mathrm{N}$ fixation and atmospheric deposition), manure application technique, soil type, land use and precipitation (Lesschen et al., 2011). NO emissions are linearly related to $\mathrm{N}_{2} \mathrm{O}$ emissions.

Losses of $\mathrm{N}$ from agricultural systems to ground- and surface waters accounted for in the model include (i) leaching from stored manure to groundwater, (ii) surface runoff to surface waters, (iii) subsurface runoff to surface waters, and (iv) leaching to groundwater (Fig. 1). Leaching from stored manure to groundwater is calculated by multiplying the amount of $\mathrm{N}$ stored by leaching fractions that depend on the storage system (liquid or solid manure) and the presence of concrete floors. Data on the distribution of the storage systems and the percentage of covered manure storage in countries were derived from GAINS (Klimont and Brink, 2004). Surface runoff is calculated as a fraction of the various $\mathrm{N}$ inputs, using runoff fractions that depend on slope, precipitation, land cover, soil type and soil depth (Velthof et al., 2009). The sum of $\mathrm{N}$ leaching and subsurface runoff from soils is derived by multiplying the $\mathrm{N}$ surplus by leaching fractions, which are determined based on soil texture, land use, precipitation surplus, soil organic carbon content, temperature and rooting depth (Velthof et al., 2009). The remaining fraction is assumed to be denitrification to $\mathrm{N}_{2}$. The $\mathrm{N}$ surplus in soils is calculated from the total $\mathrm{N}$ input, corrected for gaseous $\mathrm{N}$ losses and surface runoff losses directly following application, and the $\mathrm{N}$ removal via harvested crops. The division of total $\mathrm{N}$ losses to water over leaching and subsurface runoff is based on the water fluxes in both directions, which is based on Keuskamp et al. (2012). Indirect $\mathrm{N}_{2} \mathrm{O}$ emissions from $\mathrm{N}$ leached to ground- and surface waters are calculated using IPCC (2006) emission factors.

Three types of grasslands (intensively and extensively managed grasslands, and rough grazing), 30 crop types and eight animal categories (dairy cows, other cows, pigs, laying hens, other poultry, horses, sheep and goats and fur animals) are distinguished. Animal numbers for the year 2000 per NUTS2 were taken from GAINS (Klaassen et al., 2004), and (area weighted) downscaled to the FSSNUTS regions. Data on housing systems and grazing periods were also derived from GAINS, based on national data provided by national experts. Emissions are calculated for spatial units that consist of clusters of $1 \mathrm{~km}^{2}$ grid cells (NCU, NitroEurope Computational Units), characterized by similar environmental and/or agronomic conditions. For the EU27 (excluding Malta and Cyprus), 35101 NCUs were distinguished and 744 FSSNUTS regions. To avoid confusion with the EU25 established in 2004, i.e. EU27 without Bulgaria and Romania, we used "EU27" to depict the analysed member states in this study. 


\section{Uncertainty quantification and uncertainty analysis}

\subsection{Overall approach}

Model output uncertainty is determined by three categories of uncertainty sources: (1) model input uncertainty, (2) model structure uncertainty, and (3) model solution uncertainty. In this paper we solely focussed on model input uncertainty. We assumed that model solution uncertainty, which refers to errors caused by rounding, numerical evaluation of integrals, suboptimal optimization solutions, etc., has a marginal contribution to the output uncertainty and can therefore be ignored. Uncertainties due to model structure are not easy to quantify. A possible approach is to compare results of INTEGRATOR with results from other models, which has been done by De Vries et al. (2011b).

In this study we performed both an uncertainty quantification (UQ) and uncertainty analysis (UA) using a Monte Carlo (MC) simulation approach. Attractive properties of the MC method are easy implementation, general applicability and resulting in an entire probability distribution of the model output (Heuvelink, 1998). The UQ analyses how uncertainties in model inputs and model parameters propagate to the model output, while UA quantifies the contribution of individual sources of uncertainty to the output uncertainty. The application of UQ and UA involved the following steps:

1. Select model input parameters to be included in the uncertainty propagation analysis.

2. Parameterize the probability distribution of the uncertain inputs.

3. Generate realizations of the uncertain inputs by random drawing from their probability distributions.

4. Submit realizations to INTEGRATOR and perform MC runs.

5. Calculate summary measures of the outputs of the MC runs (e.g. mean, standard deviation, confidence limits).

For UQ we considered all model inputs parameters as uncertain, ranging from activity data to model constants. For UA we selected groups of model parameters for which we estimated the uncertainty contribution.

INTEGRATOR was applied while using the NCU as the spatial support, implying that spatial variability within an NCU was not taken into account. The size of the NCUs was highly variable with a mean area of $163 \mathrm{~km}^{2}$ and standard deviation of $557 \mathrm{~km}^{2}$. Larger NCUs occur mainly in flat areas with uniform soil types, whereas small NCUs occur in mountainous areas with variable soils.

\subsection{Assessment of the uncertainty of the INTEGRATOR model inputs}

The UQ focussed on analysis of propagation of uncertainty in (1) initial values (i.e. values of state variables at the start of the simulation), (2) model parameters and (3) environmental constants and variables. In the sequel these three groups are referred to as "model inputs". Uncertainties in categorical data such as land use and soil maps were not considered. The uncertainty in model input data was limited to model inputs affecting (i) $\mathrm{N}$ inputs to the system, i.e. $\mathrm{N}$ fixation, $\mathrm{N}$ deposition, $\mathrm{N}$ manure input and $\mathrm{N}$ fertilizer, and (ii) $\mathrm{N}$ fluxes in and from the ecosystems. For each model input included in the UQ we defined the following statistical properties:

1. Uncertainty in terms of coefficient of variation (CV) or standard deviation (SD), distribution type (normal or lognormal), minimum (min) and maximum (max) at NCU level.

2. Cross correlation for certain pairs of model inputs $i$ and $j\left(\rho_{\mathrm{cc}}(i, j)\right)$.

3. Spatial correlation coefficients between locations within the different spatial scale levels.

In assessing the uncertainty of model inputs and their spatial correlation, we distinguished four spatial scale levels in order of increasing size: (i) 35101 NCUs characterized by similar environmental and agronomic conditions, (ii) 744 FSSNUTS regions, (iii) 25 countries, and (iv) EU27 as a whole. An example of these spatial levels is presented for the Netherlands and surroundings in Fig. 2.

For model inputs with assumed lognormal distributions; the spatial and cross-correlations of these variables were defined at the log-transformed scale. We used a lognormal distribution when data showed that the variable has a skew distribution. The tails of the distribution can have a marked influence on model outcomes and it is important to take this into account. Details of each aspect are further described below.

\subsubsection{Values used for coefficient of variation and standard deviation}

To characterize the uncertainty in model inputs, we used the $\mathrm{CV}$ for normally distributed model inputs, assuming that the $\mathrm{SD}$ is proportional to the average value of a model input. For lognormal model inputs we used the conventional approach and defined the uncertainty by the SD at the log-transformed scale, being approximately equal to the $\mathrm{CV}$ on the original scale (Limpert et al., 2001).

Because we have little quantitative information on the uncertainty of the model inputs, we decided to use only three levels of $\mathrm{CVs}$, i.e. low $(\mathrm{CV}=0.10)$, moderate $(\mathrm{CV}=0.25)$ and high $(\mathrm{CV}=0.50)$, with the following assignments: 


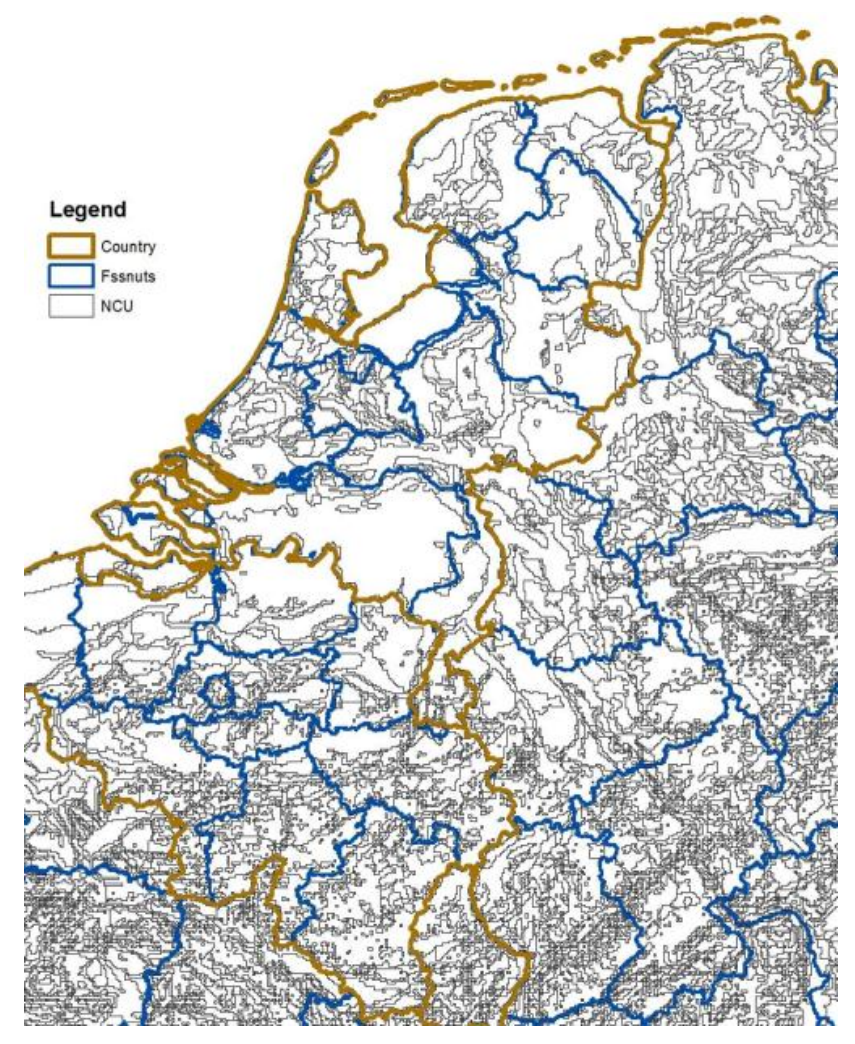

Fig. 2. Map of the Netherlands depicting the NCU, FSSNUTS, and Country spatial aggregation levels.

- Low - used for model inputs based on accurate quality statistics for agronomic data (i.e. animal numbers, national $\mathrm{N}$ fertilizer inputs and $\mathrm{N}$ input data) and also for the crop uptake efficiency fractions.

- High - used for guestimated model inputs, such as $\mathrm{N}_{2} \mathrm{O}$ emission fractions from solid manure systems and $\mathrm{N}$ fixation for arable land and grassland.

- Moderate - used for all other model inputs.

The normal distribution was used as a standard, except for (i) all $\mathrm{N}_{2} \mathrm{O}$ and $\mathrm{NO}$ emission fractions, and (ii) the ratio between $\mathrm{NO}_{\mathrm{x}}$ and $\mathrm{N}_{2} \mathrm{O}$ emission fractions. These model inputs, with a strongly positive skew distribution, were considered lognormally distributed.

Since the information on the assigned CVs was largely based on expert judgement, we applied a robustness analysis by using three uncertainty scenarios (Optimistic $(\mathrm{O})$, Reference (R) and Pessimistic (P)). For the CVs, explicit values were assigned for each scenario (see Table 1).

In order to prevent physically unrealistic values, we set (i) a minimum of 0 and a maximum of 1 in case of fractions, and (ii) in other cases a physical minimum (generally 0 , sometimes minus infinity) and a physical maximum (generally infinity).
Table 1. Values used for CVs in three scenarios to assess the robustness of the uncertainty analysis.

\begin{tabular}{lrrr}
\hline Class of CV & Opt (O) & $\operatorname{Ref}(\mathrm{R})$ & Pes (P) \\
\hline Low CV (L) & 0.05 & 0.10 & 0.15 \\
Moderate CV (M) & 0.10 & 0.25 & 0.30 \\
High CV (H) & 0.40 & 0.50 & 0.60 \\
\hline
\end{tabular}

\subsubsection{Cross-correlations}

Some model inputs are correlated with other model inputs, which affects the uncertainty estimation; therefore crosscorrelations need to be considered. The considered crosscorrelations are given in Table 2. The selected pairs of correlated inputs and assigned correlations were determined by expert judgement. It is obvious that the $N$ excretion rate of cattle is positively correlated with the $N$ content of grass intensive. The negative correlation between Crop yield and the Maximum $N$ content in the harvested crops prevents the occurrence of unrealistic values of crop removal (in terms of $\mathrm{N})$. Although processes related to $\mathrm{N}_{2} \mathrm{O}$ emission and $\mathrm{NH}_{3}$ emission are different, we also included a correlation between the $\mathrm{NH}_{3}$ emission fraction from housing systems and those for $\mathrm{N}_{2} \mathrm{O}$ emission fraction from housing systems. This was done since "open" stables or non-covered manure storages leading to a high $\mathrm{NH}_{3}$ emission also result in a higher $\mathrm{N}_{2} \mathrm{O}$ emission. Since $\mathrm{NO}$ and $\mathrm{N}_{2} \mathrm{O}$ emission from housing systems are highly interconnected processes, we assigned a high correlation between the emission fractions for these $\mathrm{N}$ forms.

\subsubsection{Spatial correlations}

In addition to cross-correlations, spatial correlation of uncertain inputs was considered as well. Uncertainty about spatially distributed inputs tends to be positively spatially correlated, and this influences the degree to which uncertainties cancel out by spatial aggregation (see e.g. Heuvelink and Pebesma, 1999). The common geostatistical procedure to include spatial correlations in uncertain inputs is to define variograms and determine for each model input the sill, nugget, range and shape of the variogram. Cross-variograms are also needed for inputs that are cross-correlated. Since hardly any data are available to derive these variograms and cross-variograms, we included spatial correlation using a pragmatic approach as suggested by Lesschen et al. (2007). They incorporated the degree of spatial correlation as an effect on the variance of the aggregated results.

The methodology by Lesschen et al. (2007) is also attractive because (i) it can easily be applied in a situation with variable support, whereas the geostatistical procedure assumes a constant support, and (ii) it can take explicit differences between countries into account, e.g. due to legislation and/or country-specific management, whereas the 
Table 2. Model inputs for which cross-correlations are included.

\begin{tabular}{llr}
\hline Model input 1 & Model input 2 & $\rho_{\mathrm{cc}}$ \\
\hline $\mathrm{N}$ excretion rate of cattle & N content of grass intensive & 0.5 \\
Crop yield & Maximum N content in the harvested crops & -0.8 \\
$\mathrm{NH}_{3}$ emission fraction from housing systems & $\mathrm{N}_{2} \mathrm{O}$ emission fraction from housing systems & 0.5 \\
$\mathrm{~N}_{2} \mathrm{O}$ emission fraction from housing systems & NO emission fraction from housing systems & 0.8 \\
\hline
\end{tabular}

geostatistical procedure cannot cope easily with administrative boundaries.

The degree of spatial correlation was defined as the correlation between inputs in (i) different NCUs within the same FSSNUTS region $\left(\rho_{\mathrm{NCU}}\right)$, (ii) different FSSNUTS regions within the same country ( $\rho_{\text {NUTS }}$ ), and (iii) different countries within EU27 ( $\rho_{\text {COUNTRY }}$ ). The uncertainty of inputs at NCU level was assumed to be constant and independent of the size of the NCU. The uncertainty of most inputs, however, was only available at either FSSNUTS level, e.g. animal numbers, or at national level, e.g. fertilizer amounts and model inputs on $\mathrm{N}$ excretion, distribution and emission. For model inputs whose uncertainty was defined at FSSNUTS or country level, the value of $\rho_{\mathrm{NCU}}$ was set to 1 (perfect correlation). We also assumed that there was no spatial variability within NCUs, thus correlations within an NCU were always 1.

To complete the definition of uncertainties in spatial inputs with probability distributions, the next step was to specify the spatial cross-correlation coefficients between a model input at some location with another model input at another location. These were calculated as

$$
\begin{aligned}
& \rho_{\mathrm{NCU}}(i, j)=\rho_{\mathrm{cc}}(i, j) \cdot \sqrt{\rho_{\mathrm{NCU}}(i) \cdot \rho_{\mathrm{NCU}}(j)} \\
& \rho_{\mathrm{NUTS}}(i, j)=\rho_{\mathrm{cc}}(i, j) \cdot \sqrt{\rho_{\mathrm{NUTS}}(i) \cdot \rho_{\mathrm{NUTS}}(j)} \\
& \rho_{\mathrm{COUNTRY}}(i, j)=\rho_{\mathrm{cc}}(i, j) \\
& \cdot \sqrt{\rho_{\mathrm{COUNTRY}}(i) \cdot \rho_{\mathrm{COUNTRY}}(j)},
\end{aligned}
$$

where $i$ and $j$ refer to model inputs $i$ and $j$ and where $\rho_{\mathrm{cc}}(i, j)$ is the correlation coefficient between model inputs $i$ and $j$ for the same plot.

We limited the number of values for the spatial correlation coefficients $\rho$ to five classes:

- Perfect - for model inputs that are not linked to the NCU but to a higher aggregation level.

- High - in case of a strong spatial correlation.

- Moderate - in case of a moderate spatial correlation.

- Low - in case of a weak spatial correlation.

- None - in case of no spatial correlation.

Furthermore, as with the CV, we used three scenarios (Optimistic (O), Reference (R) and Pessimistic (P)) to investigate the robustness of the assigned correlations. The values of the
Table 3. Values of spatial correlation coefficients for three robustness scenarios.

\begin{tabular}{lrrr}
\hline Class of correlation & Opt (O) & Ref (R) & Pes (P) \\
\hline Perfect (P) & 1.0 & 1.0 & 1.0 \\
High (H) & 0.8 & 0.85 & 0.9 \\
Moderate (M) & 0.3 & 0.5 & 0.7 \\
Low (L) & 0.1 & 0.2 & 0.3 \\
None (N) & 0.0 & 0.0 & 0.0 \\
\hline
\end{tabular}

spatial correlation coefficients in all these cases are given in Table 3.

\subsubsection{Generation of multiple model inputs}

We generated sets of multiple model inputs randomly drawn from the input distribution functions, using the rmultnorm function from the MSBVAR library in $\mathrm{R}$ (http://www. r-project.org/) and linking each model input to the NCU, NUTS, Country or EU27 level. Spatial correlation coefficient matrices were built by linking all model inputs to each of the $35101 \mathrm{NCUs}$, while incorporating the $\rho_{\mathrm{NCU}}, \rho_{\mathrm{NUTS}}$ and $\rho_{\text {COUNTRY }}$ coefficients. At the same time the crosscorrelations were taken into account.

Based on preliminary testing, we decided to perform $1000 \mathrm{MC}$ runs. With this relatively high number of MC runs, the predefined distributions and their correlation structure were adequately represented. The analysis was done for the three robustness scenarios, so in total three sets of $1000 \mathrm{MC}$ runs were generated.

\subsection{Quantification of the uncertainty contribution}

The INTEGRATOR model includes a large number of model inputs, which hampers the quantification of the uncertainty contribution of individual parameters. Therefore, we decided to quantify the contribution of model inputs to the uncertainty in model outputs for groups of model inputs affecting certain model outputs, such as $\mathrm{N}$ excretion, $\mathrm{N}$ emission, $\mathrm{N}$ uptake, etc. We grouped the INTEGRATOR inputs into six groups for which we analysed the uncertainty separately (see column "Group" in Table 4). For each individual model input the uncertainty contribution to the total output uncertainty was estimated. This was accomplished by a MC simulation considering only the model input group uncertain for 


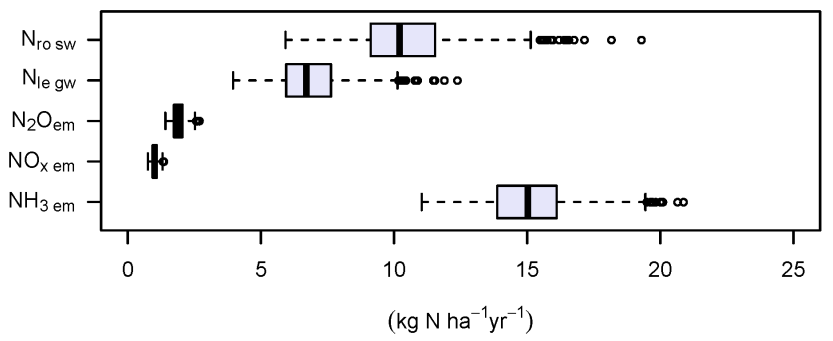

Fig. 3. Boxplots with $95 \%$ prediction interval and outliers of the area-weighted average (per $\mathrm{NCU}) \mathrm{N}_{2} \mathrm{O}$ emission $\left(\mathrm{N}_{2} \mathrm{O}_{e m}\right), \mathrm{NO}_{\mathrm{x}}$ emission $\left(\mathrm{NO}_{\mathrm{x}} \mathrm{em}\right), \mathrm{NH}_{3}$ emission $\left(\mathrm{NH}_{3} \mathrm{em}\right), \mathrm{N}$ leaching to groundwater $\left(\mathrm{N}_{\text {le gw }}\right)$ and $\mathrm{N}$ runoff to surface water $\left(\mathrm{N}_{\text {ro sw }}\right)$ for the EU27 for the year 2000 .

which the contribution was to be estimated. The other six groups were considered certain by using their default values as stored in the INTEGRATOR database. Hence, the model was run again in six separate rounds, and each time only one of the six groups was made uncertain. The uncertainty contribution was based on a comparison of the resulting output variances of each model input group. The analysed model inputs (51 in total) and their statistical properties and spatial levels are given in Table 4.

\section{Results}

\subsection{Uncertainty in model outputs}

\subsubsection{Uncertainty at EU27 and country level}

Results at EU27 level show larger uncertainties for N leaching to groundwater and $\mathrm{N}$ runoff to surface water (relative errors of $\sim 19 \%$ ), and smaller uncertainties for the emission of $\mathrm{N}_{2} \mathrm{O}, \mathrm{NO}_{\mathrm{x}}$ and $\mathrm{NH}_{3}$ (relative errors of $\sim 12 \%$ ) (Fig. 3 and Table 5).

The larger uncertainties in $\mathrm{N}$ runoff to surface water and $\mathrm{N}$ leaching to groundwater are caused by the larger number of uncertain model inputs affecting excretion, emission, nitrogen input, nitrogen uptake and leaching and runoff, whereas the uncertainties in $\mathrm{N}_{2} \mathrm{O}, \mathrm{NO}_{\mathrm{x}}$ and $\mathrm{NH}_{3}$ are affected by fewer uncertain model inputs, i.e. excretion and emission (see Table 4).

The uncertainties can vary considerably among countries (Table 6). Some countries have large uncertainties for all outputs, e.g. Austria, whereas other countries have relatively high uncertainties for only one output, e.g. Denmark for N leaching to groundwater. As shown in Table 5, the uncertainties in the average emissions and leaching fluxes at European level are noticeably smaller than those at country level. The average relative uncertainty for $\mathrm{N}_{2} \mathrm{O}$ at country level is $16 \%$ (Table 6), whereas at EU27 level it decreases to $12 \%$ (Table 5).

\subsubsection{Spatial distribution of uncertainty at NCU level}

Figures 4 and 5 depict the spatial variability of the areaweighted average $\mathrm{N}\left(\mathrm{N}_{2} \mathrm{O}, \mathrm{NH}_{3}\right.$ and $\left.\mathrm{NO}_{\mathrm{x}}\right)$ emissions (Fig. 4) and $\mathrm{N}$ losses to groundwater and to surface water (Fig. 5) within the EU27 at NCU level for the year 2000. The figures show the mean values and the relative uncertainty expressed as a CV. The results show that $\mathrm{N}$ fluxes are highly correlated with agricultural intensity. High fluxes occur in areas with a high intensity of animal husbandry, such as the Po Valley, northern Germany, the Netherlands and Bretagne, and hilly regions such as the Alps in southern Germany and northern Spain (see e.g. Leip et al., 2011a). Compared to other outputs, $\mathrm{NH}_{3}$ emissions show a smaller spatial variation. $\mathrm{NH}_{3}$ emissions are related to livestock manure production and manure application, which are provided at FSSNUTS level, whereas $\mathrm{N}_{2} \mathrm{O}$ and $\mathrm{NO}_{\mathrm{x}}$ fluxes and $\mathrm{N}$ leaching and runoff fluxes also are largely influenced by the underlying environmental conditions such as soil type and hydrological conditions, which are linked to the NCU level.

The variation in the uncertainty of the $\mathrm{N}_{2} \mathrm{O}$ and $\mathrm{NO}_{\mathrm{x}}$ emission among the NCUs is relatively small, and varies mostly between 20 and $40 \%$. The uncertainty at country level is lower, generally below $20 \%$ for both $\mathrm{N}_{2} \mathrm{O}$ and $\mathrm{NO}_{\mathrm{x}}$ (Table 6).

The spatial variation of the uncertainty of $\mathrm{NH}_{3}$ emission at $\mathrm{NCU}$ level is somewhat larger and apparently distributed into two classes, either less than $20 \%$ or between 20 and $40 \%$. It seems that areas with a higher uncertainty are areas where most of the $\mathrm{NH}_{3}$ emission is caused by grazing and manure application, such as in Spain and Ireland.

Contrary to the gaseous emissions (Fig. 4), N runoff to surface water and especially $\mathrm{N}$ leaching to groundwater show a relatively large spatial variation (Fig. 5). In large parts of Central and Northern Europe, but also in parts of the UK, Ireland, France, Spain and Italy the uncertainty at NCU level of $\mathrm{N}$ leaching to groundwater is even larger than $100 \%$. For $\mathrm{N}$ runoff to surface water there are fewer areas with an uncertainty of more than $100 \%$. Large uncertainties in N leaching to groundwater generally occur in countries with a relatively large area of sandy soils, for which the uncertainty is large compared to clay and peat soils, as sandy soils generally receive higher $\mathrm{N}$ inputs and are more susceptible to leaching (not shown). Moreover, the large variation in the uncertainty for leaching and runoff is mostly due to the leaching fraction and runoff fractions, which are related to soil type, texture and organic matter.

Uncertainties increase when going from EU27 level to country level to NCU level, as shown in Table 7. This table shows that the uncertainties (expressed as CV) for the outputs at NCU level are $\sim 3$ times greater, and at country level $\sim 1.35$ times greater than the uncertainties at EU27 level. 
Table 4. Statistical properties and spatial levels of uncertain model inputs.

\begin{tabular}{|c|c|c|c|c|c|c|}
\hline Model input ${ }^{1}$ & Spatial $^{2}$ Level & Distrib. $^{3}$ & $\mathrm{CV}^{4}$ & $\rho_{\mathrm{NCU}}^{5}$ & $\rho_{\text {NUTS }}^{5}$ & $\rho_{\text {COUNTRY }}^{5}$ \\
\hline \multicolumn{7}{|l|}{ Livestock excretion data } \\
\hline Animal numbers, dairy cattle (head) & NAT & $\mathrm{N}$ & $\mathrm{L}$ & $\mathrm{P}$ & $\mathrm{P}$ & M \\
\hline Animal numbers, other cattle (head) & NAT & $\mathrm{N}$ & $\mathrm{L}$ & $\mathrm{P}$ & $\mathrm{P}$ & M \\
\hline Animal numbers, pigs and poultry (head) & NAT & $\mathrm{N}$ & $\mathrm{L}$ & $\mathrm{P}$ & $\mathrm{P}$ & M \\
\hline Animal numbers, other animals (head) & NAT & $\mathrm{N}$ & $\mathrm{L}$ & $\mathrm{P}$ & $\mathrm{P}$ & M \\
\hline $\mathrm{N}$ excretion rates, dairy cattle $\left(\mathrm{kg} \mathrm{N}\right.$ head $\left.^{-1}\right)$ & NUT & $\mathrm{N}$ & M & $\mathrm{P}$ & $\mathrm{H}$ & M \\
\hline $\mathrm{N}$ excretion rates, other cattle $\left(\mathrm{kg} \mathrm{N}\right.$ head $\left.{ }^{-1}\right)$ & NUT & $\mathrm{N}$ & M & $\mathrm{P}$ & $\mathrm{H}$ & M \\
\hline $\mathrm{N}$ excretion rates, pigs and poultry $\left(\mathrm{kg} \mathrm{N}\right.$ head $\left.^{-1}\right)$ & NUT & $\mathrm{N}$ & M & $\mathrm{P}$ & $\mathrm{H}$ & M \\
\hline $\mathrm{N}$ excretion rates, other animals (horses, sheep and goats and other animals) ( $\mathrm{kg} \mathrm{N}$ head $^{-1}$ ) & NUT & $\mathrm{N}$ & M & $\mathrm{P}$ & $\mathrm{L}$ & $\mathrm{L}$ \\
\hline Housing fractions, dairy cattle $(-)$ & NUT & $\mathrm{N}$ & M & $\mathrm{P}$ & M & $\mathrm{L}$ \\
\hline Housing fractions, other cattle $(-)$ & NUT & $\mathrm{N}$ & M & $\mathrm{P}$ & M & $\mathrm{L}$ \\
\hline Fraction of excreted amount stored as liquid manure in the housing system, cattle (-) & NUT & $\mathrm{N}$ & M & $\mathrm{P}$ & $\mathrm{H}$ & M \\
\hline Fraction of excreted amount stored as liquid manure in the housing system, pigs and poultry (-) & NUT & $\mathrm{N}$ & M & $\mathrm{P}$ & $\mathrm{H}$ & M \\
\hline \multicolumn{7}{|l|}{ Livestock emission data } \\
\hline $\mathrm{NH}_{3}$ emission fraction from housing systems (-) & NUT & $\mathrm{N}$ & M & $\mathrm{P}$ & $\mathrm{H}$ & M \\
\hline $\mathrm{NH}_{3}$ emission fraction from manure storage systems (-) & NUT & $\mathrm{N}$ & M & $\mathrm{P}$ & $\mathrm{H}$ & M \\
\hline $\mathrm{N}_{2} \mathrm{O}$ emission fraction from housing systems (liquid) $(-)$ & NUT & $\mathrm{L}$ & M & $\mathrm{P}$ & $\mathrm{H}$ & M \\
\hline $\mathrm{N}_{2} \mathrm{O}$ emission fraction from manure storage systems (liquid) (-) & NUT & $\mathrm{L}$ & M & $\mathrm{P}$ & $\mathrm{H}$ & M \\
\hline NO emission fraction from housing systems (liquid) $(-)$ & NUT & $\mathrm{L}$ & M & $\mathrm{P}$ & $\mathrm{H}$ & M \\
\hline NO emission fraction from manure storage systems (liquid) $(-)$ & NUT & $\mathrm{L}$ & M & $\mathrm{P}$ & $\mathrm{H}$ & M \\
\hline $\mathrm{N}_{2} \mathrm{O}$ emission fraction from housing systems (solid) $(-)$ & NUT & $\mathrm{L}$ & $\mathrm{H}$ & $\mathrm{P}$ & $\mathrm{H}$ & M \\
\hline $\mathrm{N}_{2} \mathrm{O}$ emission fraction from manure storage systems (solid) (-) & NUT & $\mathrm{L}$ & $\mathrm{H}$ & $\mathrm{P}$ & $\mathrm{H}$ & M \\
\hline NO emission fraction from housing systems (solid) $(-)$ & NUT & $\mathrm{L}$ & $\mathrm{H}$ & $\mathrm{P}$ & $\mathrm{H}$ & M \\
\hline NO emission fraction from manure storage systems (solid) $(-)$ & NUT & $\mathrm{L}$ & $\mathrm{H}$ & $\mathrm{P}$ & $\mathrm{H}$ & M \\
\hline \multicolumn{7}{|l|}{ Nitrogen input data } \\
\hline Allocation fraction for arable and grassland in the manure and $\mathrm{N}$ input assessment procedure (-) & NUT & $\mathrm{N}$ & M & $\mathrm{P}$ & M & $\mathrm{L}$ \\
\hline Weighing factor for grassland and fodder in the manure and $\mathrm{N}$ input assessment procedure (-) & NUT & $\mathrm{N}$ & M & $\mathrm{P}$ & M & $\mathrm{L}$ \\
\hline Areas of intensively and extensively managed grassland (Area_ext $=$ Area_grass- Area_int) $(-)$ & NUT & $\mathrm{N}$ & M & $\mathrm{P}$ & M & $\mathrm{L}$ \\
\hline National fertilizer $\mathrm{N}$ inputs (ton $\mathrm{N}$ country ${ }^{-1}$ ) & NAT & $\mathrm{N}$ & $\mathrm{L}$ & $\mathrm{P}$ & $\mathrm{P}$ & M \\
\hline $\mathrm{N}$ deposition data $\left(\mathrm{kg} \mathrm{N} \mathrm{ha}^{-1}\right)$ & $\mathrm{NCU}$ & $\mathrm{N}$ & M & M & $\mathrm{L}$ & $\mathrm{L}$ \\
\hline $\mathrm{N}$ fixation, arable (arable + fodder) $\left(\mathrm{kg} \mathrm{N} \mathrm{ha}^{-1}\right)$ & $\mathrm{NCU}$ & $\mathrm{N}$ & $\mathrm{H}$ & M & $\mathrm{L}$ & $\mathrm{L}$ \\
\hline $\mathrm{N}$ fixation, grass (int +ext $\left(\mathrm{kg} \mathrm{N} \mathrm{ha}^{-1}\right)$ & $\mathrm{NCU}$ & $\mathrm{N}$ & $\mathrm{H}$ & M & $\mathrm{L}$ & $\mathrm{L}$ \\
\hline $\mathrm{N}$ fixation, legume $\left(\mathrm{kg} \mathrm{N}^{-1}\right)$ & $\mathrm{NCU}$ & $\mathrm{N}$ & M & M & $\mathrm{L}$ & $\mathrm{L}$ \\
\hline m Availability fraction of $\mathrm{N}$ deposition compared to $\mathrm{N}$ fertilizer (-) & GEN & $\mathrm{N}$ & M & $\mathrm{P}$ & $\mathrm{P}$ & $\mathrm{P}$ \\
\hline $\begin{array}{l}\text { Availability fraction of organic } \mathrm{N} \text { in animal manure (either applied or excreted by grazing) in crop residues } \\
\text { and from soil mineralized } \mathrm{N} \text { compared to } \mathrm{N} \text { fertilizer () for arable land and grassland (-) }\end{array}$ & GEN & $\mathrm{N}$ & M & $\mathrm{P}$ & $\mathrm{P}$ & $\mathrm{P}$ \\
\hline $\mathrm{N}$ leaching fractions from stored manure $(-)$ & NUT & $\mathrm{N}$ & $\mathrm{H}$ & $\mathrm{P}$ & $\mathrm{H}$ & M \\
\hline \multicolumn{7}{|l|}{ Nitrogen uptake/immobilization data } \\
\hline Yields, arable (ton FW ha ${ }^{-1}$ ) & $\mathrm{NCU}$ & $\mathrm{N}$ & M & $\mathrm{H}$ & M & $\mathrm{L}$ \\
\hline Yields, fodder (ton $\mathrm{FW} \mathrm{ha}^{-1}$ ) & $\mathrm{NCU}$ & $\mathrm{N}$ & $\mathrm{M}$ & $\mathrm{H}$ & $\mathrm{M}$ & $\mathrm{L}$ \\
\hline Yields, grass intensive (ton $\mathrm{FW} \mathrm{ha}^{-1}$ ) & $\mathrm{NCU}$ & $\mathrm{N}$ & M & $\mathrm{H}$ & $\mathrm{H}$ & M \\
\hline Yields, grass extensive (ton $\mathrm{FW} \mathrm{ha}^{-1}$ ) & $\mathrm{NCU}$ & $\mathrm{N}$ & M & $\mathrm{H}$ & M & M \\
\hline Maximum $\mathrm{N}$ content in the harvested crops, arable $\left(\mathrm{g} \mathrm{N}(\mathrm{kg} \mathrm{FW})^{-1}\right)$ & $\mathrm{NCU}$ & $\mathrm{N}$ & M & M & $\mathrm{L}$ & $\mathrm{L}$ \\
\hline Maximum $\mathrm{N}$ content in the harvested crops, fodder $\left(\mathrm{g} \mathrm{N}(\mathrm{kg} \mathrm{FW})^{-1}\right)$ & $\mathrm{NCU}$ & $\mathrm{N}$ & M & M & M & $\mathrm{L}$ \\
\hline Maximum $\mathrm{N}$ content in the harvested crops, grass intensive $\left(\mathrm{g} \mathrm{N}(\mathrm{kg} \mathrm{FW})^{-1}\right)$ & $\mathrm{NCU}$ & $\mathrm{N}$ & M & M & M & $\mathrm{L}$ \\
\hline Maximum $\mathrm{N}$ content in the harvested crops, grass extensive $\left(\mathrm{g} \mathrm{N}(\mathrm{kg} \mathrm{FW})^{-1}\right)$ & $\mathrm{NCU}$ & $\mathrm{N}$ & M & $\mathrm{H}$ & $\mathrm{H}$ & M \\
\hline $\mathrm{N}$ index $(-)$ & $\mathrm{NCU}$ & $\mathrm{N}$ & M & M & $\mathrm{L}$ & $\mathrm{L}$ \\
\hline Uptake efficiency fraction (-) & $\mathrm{NCU}$ & $\mathrm{N}$ & $\mathrm{L}$ & M & M & $\mathrm{L}$ \\
\hline Ratio between minimum and maximum $\mathrm{N}$ uptake (-) & $\mathrm{NCU}$ & $\mathrm{N}$ & M & M & M & $\mathrm{L}$ \\
\hline Soil $\mathrm{C} / \mathrm{N}$ ratio $\left(\mathrm{kg} \mathrm{C}(\mathrm{kg} \mathrm{N})^{-1}\right)$ & $\mathrm{NCU}$ & $\mathrm{N}$ & M & M & M & $\mathrm{L}$ \\
\hline Soil emission data & & & M & & & \\
\hline $\mathrm{NH}_{3}$ emission factors from soil inputs for all manure types (-) & $\mathrm{NCU}$ & $\mathrm{N}$ & M & M & M & $\mathrm{L}$ \\
\hline $\mathrm{N}_{2} \mathrm{O}$ emission fractions from soil inputs ${ }^{6}(-)$ & $\mathrm{NCU}$ & $\mathrm{N}$ & M & $\mathrm{L}$ & $\mathrm{L}$ & $\mathrm{L}$ \\
\hline Ratio between $\mathrm{NO}_{\mathrm{x}}$ and $\mathrm{N}_{2} \mathrm{O}$ emission fractions ${ }^{7}(-)$ & $\mathrm{NCU}$ & $\mathrm{L}$ & 0.75 & M & $\mathrm{L}$ & $\mathrm{L}$ \\
\hline \multicolumn{7}{|l|}{ Leaching and runoff data } \\
\hline $\mathrm{N}$ leaching fractions from the soil (-) & $\mathrm{NCU}$ & $\mathrm{N}$ & M & M & M & $\mathrm{L}$ \\
\hline Surface runoff fractions $(-)$ & $\mathrm{NCU}$ & $\mathrm{N}$ & M & M & M & $\mathrm{L}$ \\
\hline Sub-surface runoff fractions $(-)$ & $\mathrm{NCU}$ & $\mathrm{N}$ & M & $\mathrm{M}$ & $\mathrm{M}$ & $\mathrm{L}$ \\
\hline
\end{tabular}

${ }^{1}$ Given in groups of model inputs for which the uncertainty contribution has been quantified. ${ }^{2}$ NCU: NCU level, NUT: FSSNUTS level, NAT: country level and GEN: EU27 level. ${ }^{3} \mathrm{~N}$ : Normal, L: Log-normal. The given statistical moments are given as naturally log-transformed values. In case of lognormal distributions values, refer to the CV on the original scale, being approximately equal to the SD on the log transformed (e-log) scale. ${ }^{4}$ See Table $1 .{ }^{5}$ See Table $3 .{ }^{6}$ We assigned the uncertainty to each applicable emission factor, related to the different $\mathrm{N}$ sources, i.e. deposition, fixation, animal manure, fertilizer, mineralisation and crop residues. ${ }^{7}$ In INTEGRATOR, NO $\mathrm{x}_{\mathrm{x}}$ soil emissions were derived as a fraction of the $\mathrm{N}_{2} \mathrm{O}$ soil emissions. The $\mathrm{CV}$ of this fraction was based on the dataset from Stehfest and Bouwman (2006). For this parameter we used $0.5 \times \mathrm{CV}$ for the $\mathrm{O}$ scenario, $\mathrm{CV}$ for the $\mathrm{R}$ scenario and 1.5 for the $\mathrm{P}$ scenario. 

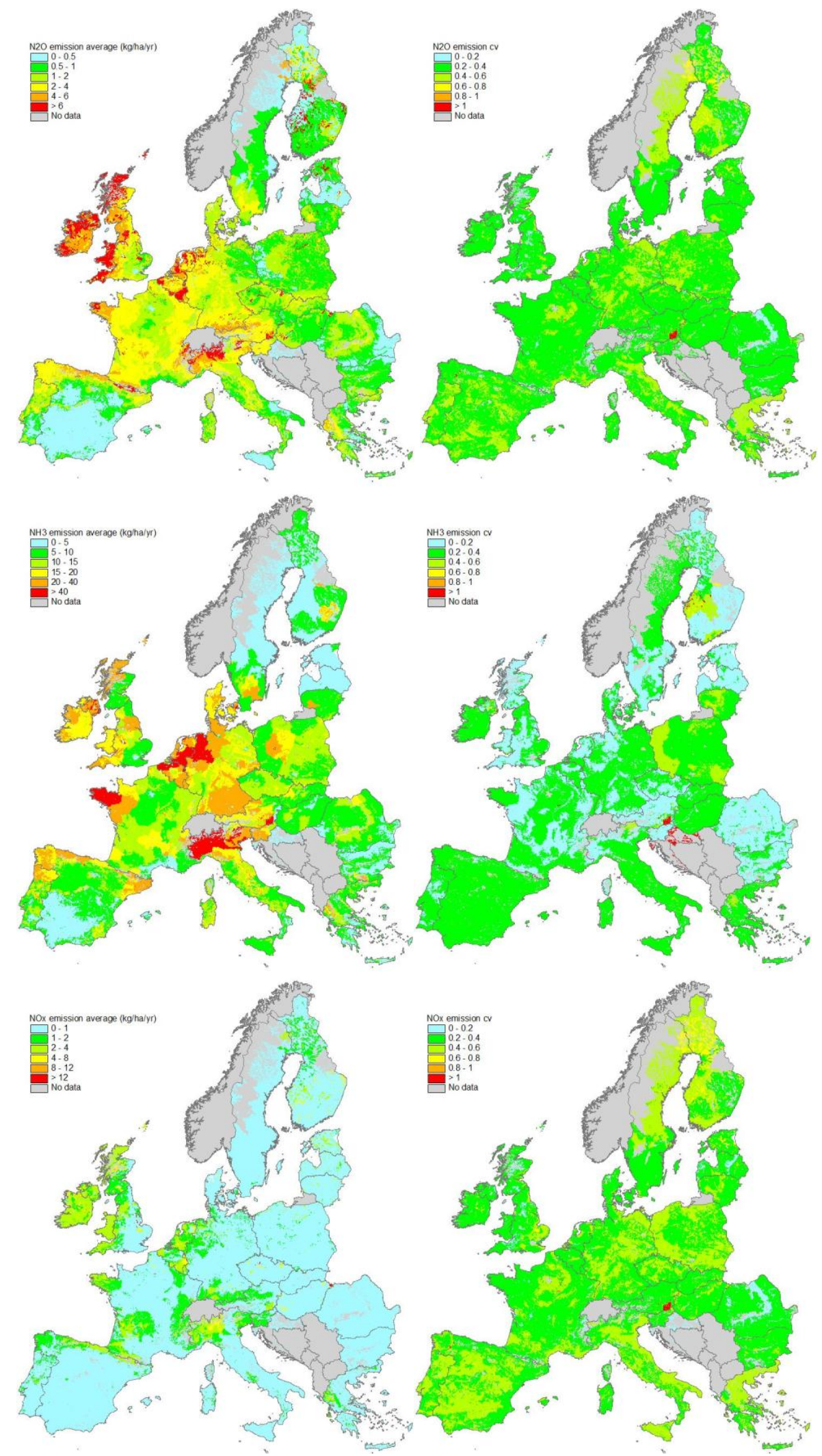

Fig. 4. The mean (left) and $\mathrm{CV}$ (right) of the area-weighted average $\mathrm{N}_{2} \mathrm{O}, \mathrm{NH}_{3}$ and $\mathrm{NO}_{\mathrm{x}}$, emission (in $\mathrm{kg} \mathrm{N} \mathrm{ha}^{-1} \mathrm{yr}^{-1}$ ) per $\mathrm{NCU}$ for the year 2000 . 


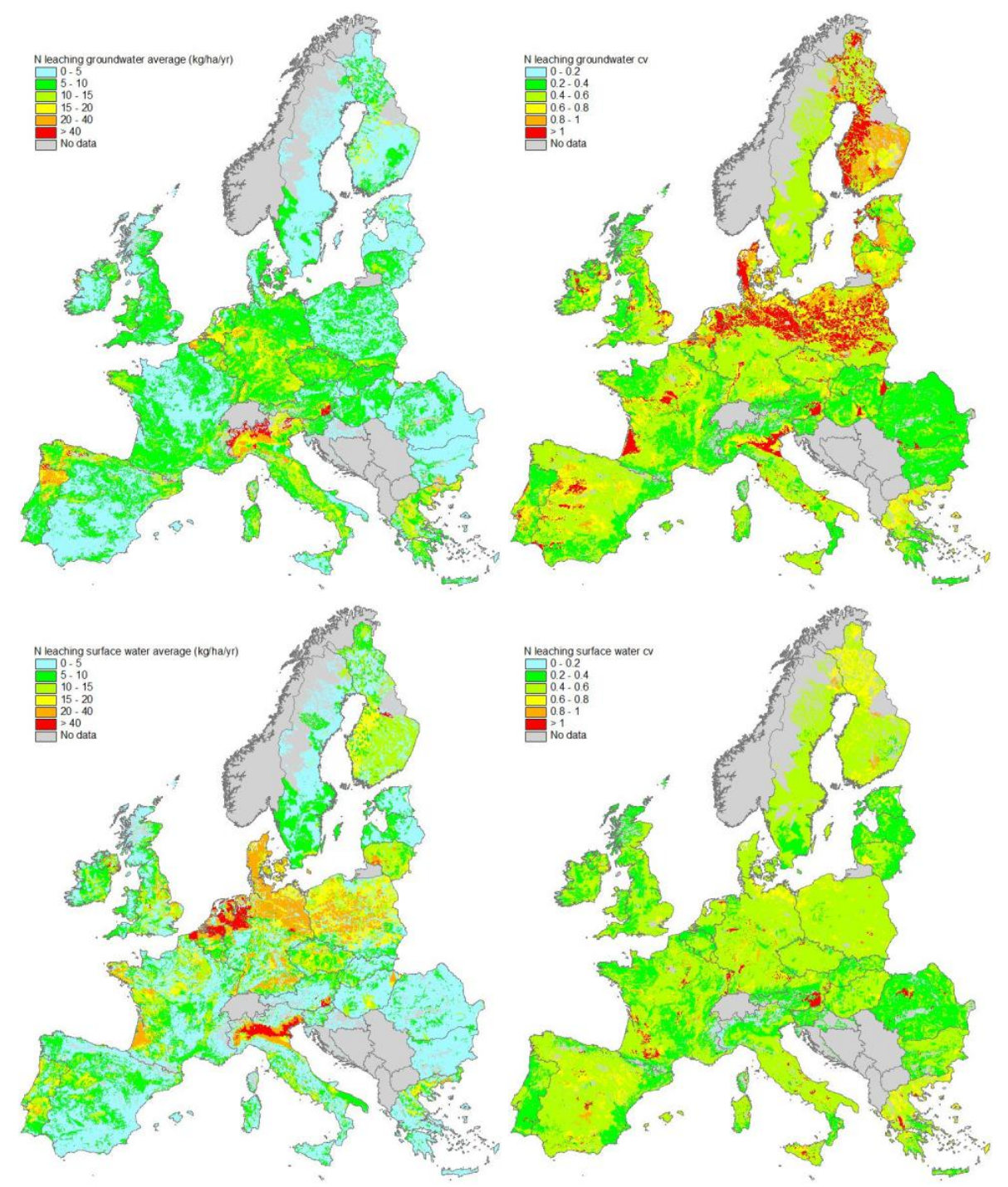

Fig. 5. The mean (left) and CV (right) of the area-weighted average $\mathrm{N}_{\text {le }}$ groundwater (top) and $\mathrm{N}_{\text {ro }}$ surface water (bottom) (in $\mathrm{kg} \mathrm{N}$ ha ${ }^{-1}$ $\mathrm{yr}^{-1}$ ) per NCU for the year 2000 .

\subsection{Uncertainty contribution of various inputs}

Uncertainty in the $\mathrm{N}_{2} \mathrm{O}$ emission is mainly caused by uncertainty in $\mathrm{N}$ inputs and crop uptake parameters (each group contribute $>20 \%$ ) and to a lesser extend to the uncertainty in housing emission (19\%), excretion (10\%) and soil emission parameters (2\%) (Fig. 6). The same is true for the NO emission, but the uncertainty contribution of the soil emission parameters $(5 \%)$ is somewhat larger and the contribution of housing emission parameters is smaller (4\%). For $\mathrm{NH}_{3}$ emissions, the largest uncertainties originated from the excretion parameters $(51 \%)$, followed by the uncertainty in $\mathrm{N}$ inputs $(20 \%)$. As with the $\mathrm{N}_{2} \mathrm{O}$ and $\mathrm{NO}$ emissions, the uncertainty contributions of the housing emission (14\%) and soil emission parameters $(2 \%)$ are rather small. The uncertainty in $\mathrm{N}$ leaching and $\mathrm{N}$ runoff is mainly caused by uncertainty in $\mathrm{N}$ inputs ( $48 \%$ and $57 \%$ resp.), $\mathrm{N}$ leaching parameters (26\% and $17 \%$ resp.) and crop uptake (13\% and $16 \%$ resp.).

\subsection{Robustness analysis}

The results of the robustness analysis are presented in Table 8. Results show that the uncertainty in $\mathrm{N}$ losses to air $\left(\mathrm{N}_{2} \mathrm{O}\right.$ emission, $\mathrm{NO}_{\mathrm{x}}$ emission, $\mathrm{NH}_{3}$ emission) or water $(\mathrm{N}$ leaching to groundwater and $\mathrm{N}$ runoff to surface water) for the EU27, expressed as CV, range from 4 to $6 \%$ for the Optimistic scenario, from 12 to $19 \%$ for the Reference scenario and from 19 to $30 \%$ for the Pessimistic scenario. The maximum values of the Optimistic and Pessimistic scenarios range from 12 to $55 \%$. The uncertainty due to the three robustness scenarios is about $50 \%\left(\mathrm{CV}_{\text {rob }}\right.$, Table 8$)$. 
Table 5. Overall uncertainty at EU27 level, expressed as mean and percentiles $\left(\mathrm{kg} \mathrm{N} \mathrm{ha}^{-1} \mathrm{yr}^{-1}\right)$ and $\mathrm{CV}$ in $\mathrm{N}_{2} \mathrm{O}$ emission $\left(\mathrm{N}_{2} \mathrm{O}_{\mathrm{em}}\right)$, $\mathrm{NO}_{\mathrm{x}}$ emission $\left(\mathrm{NO}_{\mathrm{x}} \mathrm{em}\right), \mathrm{NH}_{3}$ emission $\left(\mathrm{NH}_{3} \mathrm{em}\right), \mathrm{N}$ leaching to groundwater $\left(\mathrm{N}_{\mathrm{le} \mathrm{gw}}\right)$ and $\mathrm{N}$ runoff to surface water $\left(\mathrm{N}_{\mathrm{ro} \mathrm{sw}}\right)$ for the year 2000 .

\begin{tabular}{lrrrrrr}
\hline $\begin{array}{l}\text { Model } \\
\text { output }\end{array}$ & Mean & SD & P05 & P50 & P95 & CV \\
\hline \multicolumn{7}{c}{$\mathrm{kg} \mathrm{N} \mathrm{ha}^{-1} \mathrm{yr}^{-1}$} \\
\hline $\mathrm{N}_{2} \mathrm{O}_{\mathrm{em}}$ & 1.9 & 0.2 & 1.6 & 1.9 & 2.3 & 0.12 \\
$\mathrm{NO}_{\mathrm{x} \text { em }}$ & 1.0 & 0.1 & 0.9 & 1.0 & 1.2 & 0.11 \\
$\mathrm{NH}_{3}$ em & 15.1 & 1.6 & 12.5 & 15.0 & 17.7 & 0.11 \\
$\mathrm{~N}_{\text {le gw }}$ & 6.9 & 1.3 & 5.0 & 6.7 & 9.3 & 0.19 \\
$\mathrm{~N}_{\text {ro sw }}$ & 10.4 & 1.9 & 7.9 & 10.2 & 13.7 & 0.18 \\
\hline
\end{tabular}

Uncertainty Contribution (\%)

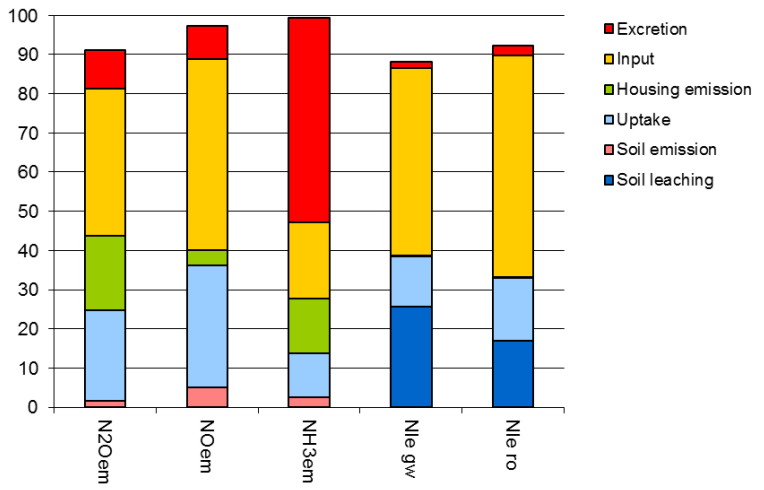

Fig. 6. Relative uncertainty contributions of individual model input groups ( $\mathrm{CV}$ in \%) to $\mathrm{N}_{2} \mathrm{O}$ emission, $\mathrm{NH}_{3}$ emission, $\mathrm{N}$ leaching to groundwater and $\mathrm{N}$ runoff to surface water for the EU27 for the year 2000 .

The robustness analysis shows that the mean $\mathrm{N}$ losses also depend on the scenario. The mean values increase when shifting from the Optimistic to the Pessimistic scenario. This is due to non-linearities and the lognormal distribution of some of the uncertain model inputs, which causes a shift towards higher values.

\section{Discussion}

\subsection{Limitations of the study}

We have used a methodology allowing inclusion of different degrees of spatial correlation in uncertain model inputs. The parameterization, i.e. both the quantification of the statistical properties and the linkage of model inputs to the spatial levels and groups, is difficult because much of the required information is lacking. Nevertheless, we tried to incorporate most of the uncertainties and their correlations. It is evident that all assumptions made influence the results. In order to compensate for these shortcomings, we included a robustness analysis with respect to the assigned uncertainties. Yet, future research should address the improvement of the parameterization of uncertainty distributions and their (spatial) correlations, but this requires that appropriate data become available. Other aspects that were not included in the uncertainty quantification deserve attention too, such as uncertainty due to model structure, and uncertainty in categorical input data, such as land use maps and soil maps.

\subsection{Plausibility of the uncertainty quantification}

Leaching fluxes to groundwater and runoff fluxes to surface water have the largest relative (CV) and absolute (SD) uncertainties. $\mathrm{NH}_{3}$ emission has the smallest relative uncertainty $(\mathrm{CV})$, but the largest absolute uncertainty (SD). In general the results show that the further in the calculation chain, and the more uncertain processes are involved, the larger the uncertainty in the outputs. Furthermore, results confirm that uncertainties and spatial variation in model outputs are partly cancelled out due to spatial aggregation.

Regarding $\mathrm{N}_{2} \mathrm{O}$ emissions, earlier studies show comparable uncertainties. Nol et al. (2010) estimated an average $\mathrm{N}_{2} \mathrm{O}$ emission at landscape scale of $20.5 \mathrm{~kg} \mathrm{~N}_{2} \mathrm{O}-\mathrm{N} \mathrm{ha}^{-1} \mathrm{yr}^{-1}$ and a standard deviation of $10.7 \mathrm{~kg} \mathrm{~N}_{2} \mathrm{O}-\mathrm{N} \mathrm{ha}^{-1} \mathrm{yr}^{-1}$, implying a relative uncertainty of $52 \%$. This is clearly larger than the uncertainty at the EU27 level from this study (12\%), but also larger than uncertainties from this study at NCU level (26$44 \%)$. The reason for the larger uncertainty might be that Nol et al. (2010) also included uncertainty on detailed management information, which is lacking in our study. Due to the different nature and character of the agricultural sources, among regions and countries, as well as by the limited number and uneven spread of the measurements concerning related emission parameters, the uncertainty in local scale estimates of $\mathrm{N}_{2} \mathrm{O}$ emissions can be rather large (Oenema et al., 2003).

At the national scale De Vries et al. (2003) estimated the uncertainty of modelled $\mathrm{N}$ fluxes from agriculture for the Netherlands. At national level they quantified a relative uncertainty of $24 \%$ for $\mathrm{N}_{2} \mathrm{O}, 16 \%$ for $\mathrm{NO}$ and $16 \%$ for the $\mathrm{NH}_{3}$ emissions, and $47 \%$ for the leaching and runoff to ground- and surface water. Except for $\mathrm{NH}_{3}$, these uncertainties are 20 to $50 \%$ larger than found in our study for the Netherlands (see Table 6). Since De Vries et al. (2003) ignored spatial correlation by assuming a perfect correlation between the uncertainties of their spatial units, it is likely that De Vries et al. (2003) overestimated the uncertainty in the national $\mathrm{N}$ fluxes.

From a global scale uncertainty analysis, Beusen et al. (2008) calculated a range of 27-38 (with a mean of 32) $\mathrm{Tg} \mathrm{yr}^{-1}$ for the global $\mathrm{NH}_{3}-\mathrm{N}$ emission from agricultural systems, i.e. a relative uncertainty of $11 \%$, which is slightly lower than the $16 \%$ from this study. In addition, Van Gijlswijk et al. (2004) performed an uncertainty assessment for the total atmospheric emissions of $\mathrm{NH}_{3}$ using a Tier 1 
Table 6. Overall uncertainty expressed as $\mathrm{CV}(\mathrm{SD} / \mathrm{Mean})$ and Mean (in kton $\mathrm{N} \mathrm{yr}^{-1}$ ) in the area-weighted average $\mathrm{N}_{2} \mathrm{O}$ emission $\left(\mathrm{N}_{2} \mathrm{O}_{\mathrm{em}}\right)$, $\mathrm{NO}_{\mathrm{x}}$ emission $\left(\mathrm{NO}_{\mathrm{x}} \mathrm{em}\right), \mathrm{NH}_{3}$ emission $\left(\mathrm{NH}_{3} \mathrm{em}\right), \mathrm{N}$ leaching to groundwater $\left(\mathrm{N}_{\text {le gw }}\right)$ and $\mathrm{N}$ runoff to surface water $\left(\mathrm{N}_{\text {ro sw }}\right)$ per country for the year 2000 .

\begin{tabular}{|c|c|c|c|c|c|c|c|c|c|c|}
\hline \multirow[t]{2}{*}{ Country } & \multicolumn{2}{|c|}{$\mathrm{N}_{2} \mathrm{O}_{\mathrm{em}}$} & \multicolumn{2}{|c|}{$\mathrm{NO}_{\mathrm{xem}}$} & \multicolumn{2}{|c|}{$\mathrm{NH}_{3 \mathrm{em}}$} & \multicolumn{2}{|c|}{$\mathrm{N}_{\text {le gw }}$} & \multicolumn{2}{|c|}{$\mathrm{N}_{\text {ro sw }}$} \\
\hline & Mean & $\mathrm{CV}$ & Mean & $\mathrm{CV}$ & Mean & $\mathrm{CV}$ & Mean & $\mathrm{CV}$ & Mean & $\mathrm{CV}$ \\
\hline Austria & 7 & 0.3 & 3 & 0.31 & 50 & 0.34 & 27 & 0.74 & 27 & 0.68 \\
\hline Belgium & 9 & 0.18 & 4 & 0.16 & 72 & 0.17 & 20 & 0.32 & 39 & 0.23 \\
\hline Bulgaria & 4 & 0.17 & 2 & 0.15 & 27 & 0.13 & 18 & 0.21 & 9 & 0.24 \\
\hline Czech Republic & 8 & 0.15 & 4 & 0.14 & 51 & 0.15 & 41 & 0.29 & 51 & 0.27 \\
\hline Denmark & 6 & 0.19 & 3 & 0.16 & 63 & 0.18 & 20 & 0.41 & 70 & 0.25 \\
\hline Estonia & 1 & 0.2 & 1 & 0.22 & 5 & 0.17 & 4 & 0.27 & 6 & 0.24 \\
\hline Finland & 3 & 0.19 & 1 & 0.19 & 10 & 0.14 & 13 & 0.34 & 22 & 0.32 \\
\hline France & 80 & 0.14 & 43 & 0.13 & 516 & 0.13 & 203 & 0.19 & 279 & 0.19 \\
\hline Germany & 48 & 0.16 & 26 & 0.14 & 529 & 0.14 & 210 & 0.28 & 376 & 0.25 \\
\hline Greece & 5 & 0.21 & 3 & 0.2 & 30 & 0.16 & 38 & 0.29 & 35 & 0.28 \\
\hline Hungary & 8 & 0.15 & 5 & 0.16 & 57 & 0.18 & 40 & 0.22 & 30 & 0.23 \\
\hline Ireland & 25 & 0.17 & 14 & 0.16 & 86 & 0.19 & 22 & 0.26 & 38 & 0.22 \\
\hline Italy & 27 & 0.14 & 17 & 0.13 & 323 & 0.14 & 159 & 0.22 & 258 & 0.19 \\
\hline Latvia & 2 & 0.14 & 1 & 0.14 & 9 & 0.15 & 6 & 0.28 & 11 & 0.2 \\
\hline Lithuania & 5 & 0.15 & 2 & 0.14 & 34 & 0.23 & 24 & 0.35 & 52 & 0.26 \\
\hline Luxembourg & 1 & 0.26 & 0 & 0.26 & 3 & 0.18 & 2 & 0.38 & 1 & 0.36 \\
\hline Netherlands & 12 & 0.19 & 7 & 0.17 & 131 & 0.16 & 31 & 0.41 & 95 & 0.26 \\
\hline Poland & 24 & 0.21 & 10 & 0.16 & 244 & 0.2 & 114 & 0.35 & 247 & 0.3 \\
\hline Portugal & 5 & 0.2 & 3 & 0.2 & 47 & 0.15 & 43 & 0.22 & 45 & 0.2 \\
\hline Romania & 11 & 0.15 & 5 & 0.11 & 100 & 0.14 & 52 & 0.17 & 39 & 0.17 \\
\hline Slovakia & 2 & 0.15 & 1 & 0.14 & 23 & 0.15 & 14 & 0.2 & 15 & 0.2 \\
\hline Slovenia & 2 & 0.2 & 1 & 0.19 & 14 & 0.14 & 5 & 0.22 & 4 & 0.21 \\
\hline Spain & 16 & 0.16 & 12 & 0.15 & 206 & 0.15 & 119 & 0.24 & 128 & 0.24 \\
\hline Sweden & 4 & 0.19 & 1 & 0.17 & 26 & 0.16 & 16 & 0.29 & 24 & 0.25 \\
\hline United Kingdom & 54 & 0.14 & 27 & 0.13 & 237 & 0.15 & 98 & 0.21 & 133 & 0.2 \\
\hline EU27 1 & 199 & 0.16 & 40 & 0.15 & 2941 & 0.16 & 1341 & 0.26 & 2039 & 0.23 \\
\hline
\end{tabular}

${ }^{1}$ Refers to the area weighted average of the CV and Mean at country level.

Table 7. Uncertainty (expressed as CV) for outputs at EU27 level, at country and NCU levels. Shown are the area-weighted average CV of $\mathrm{N}_{2} \mathrm{O}$ emission $\left(\mathrm{N}_{2} \mathrm{O}_{\mathrm{em}}\right), \mathrm{NO}_{\mathrm{x}}$ emission $\left(\mathrm{NO}_{\mathrm{x}} \mathrm{em}\right), \mathrm{NH}_{3}$ emission $\left(\mathrm{NH}_{3} \mathrm{em}\right), \mathrm{N}$ leaching to groundwater $\left(\mathrm{N}_{\text {le gw }}\right)$ and $\mathrm{N}$ runoff to surface water $\left(\mathrm{N}_{\text {ro sw }}\right)$ for the EU27 for the year 2000 .

\begin{tabular}{|c|c|c|c|c|c|}
\hline Level & $\mathrm{N}_{2} \mathrm{O}_{\mathrm{em}}$ & $\mathrm{NO}_{\mathrm{xem}}$ & $\mathrm{NH}_{3 \mathrm{em}}$ & $\mathrm{N}_{\text {le gw }}$ & $\mathrm{N}_{\text {ro sw }}$ \\
\hline \multicolumn{6}{|c|}{$(\mathrm{CV}=\mathrm{SD} / \mathrm{Mean})$} \\
\hline EU27 & 0.12 & 0.11 & 0.11 & 0.19 & 0.18 \\
\hline Country & $0.16(0.14-0.30)^{1}$ & $0.15(0.11-0.31)$ & $0.16(0.13-0.34)$ & $0.26(0.17-0.74)$ & $0.23(0.17-0.68)$ \\
\hline $\mathrm{NCU}$ & $0.35(0.26-0.44)^{2}$ & $0.37(0.37-0.45)$ & $0.26(0.18-0.39)$ & $0.58(0.38-0.88)$ & $0.49(0.36-0.58)$ \\
\hline
\end{tabular}

approach applied at the national scale. In their study, upscaling and spatial correlation were thus not relevant. They found an uncertainty of $17 \%$ in the national total $\mathrm{NH}_{3}$ emission based on a national scale MC analysis, which is almost equal to the $16 \%$ from this study. In cases of $\mathrm{NH}_{3}$ emission, we assigned the (housing) emission and excretion data to the FSSNUTS level and used a high correlation between the FSS-
NUTS regions, which may result in uncertainties close to those of Van Gijlswijk et al. (2004) (Tier 1) and De Vries et al. (2003) (perfect correlation).

Another national scale study was performed for the USA by Del Grosso et al. (2010), who estimated soil $\mathrm{N}_{2} \mathrm{O}$ emission from major commodity crops at $201 \mathrm{Gg} \mathrm{N}$ in 2007, with a $95 \%$ confidence interval of $133-304 \mathrm{Gg} \mathrm{N}$. This implies 
Table 8. Effect of optimistic and pessimistic scenarios on the overall mean (in $\mathrm{kg} \mathrm{N} \mathrm{ha}^{-1} \mathrm{yr}^{-1}$ ) and CV in the EU27-average $\mathrm{N}_{2} \mathrm{O}$ emission, $\mathrm{NO}_{\mathrm{x}}$ emission, $\mathrm{NH}_{3}$ emission, $\mathrm{N}_{\text {le }}$ groundwater and $\mathrm{N}_{\text {ro }}$ surface water for the year 2000.

\begin{tabular}{|c|c|c|c|c|c|c|c|}
\hline \multirow[t]{2}{*}{ Model output } & \multicolumn{3}{|c|}{ Mean } & \multicolumn{3}{|c|}{$\mathrm{CV}$} & \multirow[t]{2}{*}{$\mathrm{CV}_{\text {rob }}^{1}$} \\
\hline & Opt & Ref & Pes & Opt & Ref & Pes & \\
\hline $\mathrm{N}_{2} \mathrm{O}_{\mathrm{em}}$ & 1.8 & 1.9 & 2.0 & 0.04 & 0.12 & 0.19 & 0.53 \\
\hline $\mathrm{NO}_{\mathrm{xem}}$ & 1.0 & 1.0 & 1.1 & 0.04 & 0.11 & 0.18 & 0.52 \\
\hline $\mathrm{NH}_{3 \mathrm{em}}$ & 15.0 & 15.1 & 15.4 & 0.04 & 0.11 & 0.16 & 0.48 \\
\hline $\mathrm{N}_{\text {le gw }}$ & 6.2 & 6.9 & 7.5 & 0.06 & 0.19 & 0.30 & 0.54 \\
\hline $\mathrm{N}_{\text {ro sw }}$ & 9.6 & 10.4 & 11.4 & 0.06 & 0.18 & 0.28 & 0.52 \\
\hline
\end{tabular}

${ }^{1}$ Calculated as the CV of CVs for the three scenarios.

an uncertainty range of about $-35 \%$ to $+50 \%$ or a relative uncertainty of $42 \%$ at the national level. The relative uncertainty tended to be larger at the regional level, particularly in regions with low emissions. The national level uncertainty for the USA is clearly larger than the $17 \%$ from this study for the EU27 level. However, the study from Del Grosso et al. (2010) also included model structure uncertainty, which contributed $83 \%$ to the total uncertainty. The remaining $17 \%$ was due to uncertainty in model input data, implying a relative uncertainty of $7 \%(0.17 \times 42 \%)$. This is smaller than the $12 \%$ from our study. The difference might be caused by the fact that the Del Grosso study is confined to soil emission, whereas this study also included housing emissions. Moreover, the model structure uncertainty of Del Grosso et al. (2010) also included parameter uncertainty, which was considered part of the model input uncertainty in this study.

For the EU25, Schulze et al. (2009) estimated an uncertainty in total $\mathrm{N}_{2} \mathrm{O}$ emission from agriculture of $50 \%$, which was based on the IPCC guidelines 2006 (IPCC, 2006) while assuming a perfect spatial correlation. Based on the results of this study and other studies discussed here, it is likely that Schulze et al. (2009) overestimated the uncertainty in the $\mathrm{N}_{2} \mathrm{O}$ emission. Moreover, Leip (2010) thoroughly discussed the uncertainty of $\mathrm{N}_{2} \mathrm{O}$ emission estimates in GHG inventories and demonstrated the importance of correlation, if uncertainties are combined for the whole of Europe. He concluded that the uncertainty estimates tend to be underestimated for the activity data and overestimated for the emission factors. Berdanier and Conant (2012) showed that improved regional emission factors will reduce uncertainty by up to $65 \%$ for estimates of regional and global $\mathrm{N}_{2} \mathrm{O}$ emissions from crop land.

The plausibility of the INTEGRATOR results was examined by De Vries et al. (2011b) by comparing the computed mean values against estimates by three other models with different complexity and data requirements. They found that the estimated overall variation at EU27 level is small for the emissions of ammonia and nitrous oxide, but large for $\mathrm{N}$ leaching and runoff. At smaller spatial level, however, large differences in $\mathrm{N}$ output fluxes were found.
The analysis presented in our paper was limited to input uncertainty and ignored uncertainty due to model structure. However, model structural uncertainties can be large because these include the many assumptions and simplifications that any modelling exercise makes (see e.g. Del Grosso et al., 2010; Refsgaard et al., 2006; van der Sluijs, 2007). Possibilities for better insight in model structure uncertainty are to put more emphasis on the inter-comparison of results from independently developed models (Leip et al., 2011b) and by using a validation with independent observations.

\subsection{Contribution of different sources to the uncertainty}

The uncertainty of most of the considered outputs is mainly influenced by the uncertainty in model inputs that influence the $\mathrm{N}$ soil input such as the allocation of animal manure and fertilizer use. Notable is the relatively large contribution due to $\mathrm{N}$ uptake (10-30\%), whereas the contribution of emission factors (for housing and soil) both for $\mathrm{N}_{2} \mathrm{O}$ and $\mathrm{NH}_{3}$ is rather small (0-20\%). Apparently, their contribution is overruled by other uncertainties in the $\mathrm{N}$ cycle. This implies that more emphasis on collecting reliable $\mathrm{N}$ uptake data can be more helpful to reduce the uncertainty in the considered $\mathrm{N}$ fluxes for EU27, rather than putting more effort into improving emission factors. However, this low contribution of the emission factors is partly due to the choices made on the spatial correlation (cf. Table 4), which might be disputed. A robustness analysis of the uncertainty analysis could be recommended as well. For $\mathrm{N}$ leaching, the uncertainty contribution of the leaching parameters is larger compared to the gaseous $\mathrm{N}$ emissions parameters. Improving $\mathrm{N}$ leaching and runoff fractions should therefore receive more attention.

The uncertainty contribution was based on a comparison of the resulting output variances, which has some disadvantages, as the addressed uncertainty is only based on the inputs that are considered uncertain. The other inputs have fixed reference values that are not necessarily true values. In addition, the correlations between the uncertain and the fixed inputs are ignored. Although these disadvantages cannot be completely avoided, there are techniques developed to tackle the problem more thoroughly (see e.g. Jansen et al., 2000; 
Saltelli et al., 2004), but these techniques are computationally more intensive.

\section{Conclusions}

This study shows large variation in uncertainties and uncertainty contributions of the different model input sources across the various model outputs. Furthermore, the uncertainty in nitrogen fluxes differs per country.

The most prominent result of this study is that the uncertainty at the EU27 level is smaller than $30 \%$ for all considered model outputs, which is rather low. The results indicate that the uncertainty in all $\mathrm{N}$ fluxes at EU27 level is most likely in the range of 5-30\%, including all three scenarios of the robustness analysis, and increases in the direction $\mathrm{NH}_{3}<\mathrm{NO}_{\mathrm{x}}<\mathrm{N}_{2} \mathrm{O}<\mathrm{N}$ leaching and runoff. Using the reference scenario, the uncertainty in $\mathrm{N}$ fluxes varies from 11 to $19 \%$. The relative uncertainty in model outputs is $1.3-2$ times larger for the pessimistic scenario and ranges from 16 to $30 \%$, while the uncertainty is $2-3.3$ times smaller for the optimistic scenario and ranges from 4 to $6 \%$ only. The spatial variation in the uncertainty in the $\mathrm{N}$ fluxes can be large, in particular for the leaching fluxes to groundwater $\left(\mathrm{N}_{\text {le gw }}\right)$.

Uncertainties in $\mathrm{N}$ fluxes at EU27 level were smaller at larger spatial scales than at smaller spatial scales. This is in line with expectations because uncertainties in model outputs are partly cancelled out at higher scale levels due to spatial aggregation. Although an objective comparison is not straightforward, the uncertainties in $\mathrm{N}$ fluxes at EU27 level are generally smaller compared to results from other studies. Presumably most regional uncertainty assessment studies ignore spatial correlation and assume that inputs are constant over space, which leads to an overestimation of uncertainty at coarse spatial scales.

Activity data, such as $\mathrm{N}$ fertilizer, $\mathrm{N}$ manure and $\mathrm{N}$ uptake, are the main sources of uncertainty. It is advised to put more effort into obtaining reliable information about those model inputs, rather than putting more effort into improving the accuracy of emission factors.

As far as we know, this research is the first attempt to quantify the uncertainty in N fluxes at the EU27 level, while including a correlation between spatially variable model inputs, which is crucial in regional scale assessment. Unfortunately, for many of the spatially variable inputs very little information on their uncertainties was available. Therefore, the uncertainty of most of the model inputs was based on guestimates rather than real data. Further effort should be put into the gathering of spatial variable input data and quantification of associated uncertainties.
Acknowledgements. The authors gratefully acknowledge funding by the European Commission DG Research for the NitroEurope Integrated Project (grand no 017841) and ANIMALCHANGE (grand no 266018). The research is co-financed by the Dutch Ministry of Agriculture, Nature and Food Quality as part of the strategic research programmes "Sustainable spatial development of ecosystems, landscapes, seas and regions" and "Climate change", carried out by Wageningen University and Research Centre. We thank Tom Hoogland and Dennis Walvoort for implementation of algorithms.

Edited by: U. Skiba

\section{References}

Berdanier, A. B. and Conant, R. T.: Regionally differentiated estimates of cropland $\mathrm{N}_{2} \mathrm{O}$ emissions reduce uncertainty in global calculations, Global Change Biol., 18, 928-935, doi:10.1111/j.1365-2486.2011.02554.x, 2012.

Beusen, A. H. W., Bouwman, A. F., Heuberger, P. S. C., Van Drecht, G., and Van Der Hoek, K. W.: Bottom-up uncertainty estimates of global ammonia emissions from global agricultural production systems, Atmos. Environ., 42, 6067-6077, doi:10.1016/j.atmosenv.2008.03.044, 2008.

Bouwman, A. F., Lee, D. S., Asman, W. A. H., Dentener, F. J., van der Hoek, K. W., and Olivier, J. G. J.: A global high-resolution emission inventory for ammonia, Global Biogeochem. Cy., 11, 561-587, 1997.

Butterbach-Bahl, K., Nemitz, E., Zaehle, S., Billen, G., Boeckx, P., Erisman, J. W., Garnier, J., Upstill-Goddard, R., Kreuzer, M., Oenema, O., Reis, S., Schaap, M., Simpson, D., de Vries, W., Winiwarter, W., and Sutton, M. A.: Nitrogen as a threat to the European greenhouse balance in: The European Nitrogen Assessment, edited by: Sutton, M. A., Howard, C. M., Erisman, J. W., Billen, G., Bleeker, A., Grennfelt, P., van Grinsven, H., and Grizzetti, B., Cambridge University Press, Chapter 19, Cambridge, UK, 434-462, 2011.

De Vries, W., Kros, J., Oenema, O., and de Klein, J.: Uncertainties in the fate of nitrogen II: A quantitative assessment of the uncertainties in major nitrogen fluxes in the Netherlands, Nutr. Cycl. Agroecosyst., 66, 71-102, doi:10.1023/A:1023354109910, 2003.

De Vries, W., Kros, J., Reinds, G. J., and Butterbach-Bahl, K.: Quantifying impacts of nitrogen use in European agriculture on global warming potential, Current Opinion in Environmental Sustainability, 3, 291-302, 2011a.

De Vries, W., Leip, A., Reinds, G. J., Kros, J., Lesschen, J. P., and Bouwman, A. F.: Comparison of land nitrogen budgets for European agriculture by various modeling approaches, Environ. Pollut., 159, 3254-3268, doi:10.1016/j.envpol.2011.03.038, 2011 b.

Del Grosso, S. J., Ogle, S. M., Parton, W. J., and Breidt, F. J.: Estimating uncertainty in $\mathrm{N}_{2} \mathrm{O}$ emissions from U.S. cropland soils, Global Biogeochem. Cy., 24, GB1009, doi:10.1029/2009gb003544, 2010.

Dise, N. B., Ashmore, M., Belyazid, S., Bleeker, A., Bobbink, R., de Vries, W., Erisman, J. W., van den Berg, L., Spranger, T., and Stevens, C.: Nitrogen as a threat to European terrestrial biodiversity, in: The European Nitrogen Assessment, edited by: Sutton, M. A., Howard, C. M., Erisman, J. W., Billen, G., Bleeker, 
A., Grennfelt, P., van Grinsven, H., and Grizzetti, B., Cambridge University Press, Chapter 20, Cambridge, UK, 463-494, 2011.

FAO: FAOSTAT database collections, Food and Agriculture Organization of the United Nations, available at: http://faostat.fao.org/ (last access: 30 January 2012), Rome, 2010.

Freibauer, A.: Regionalised inventory of biogenic greenhouse gas emissions from European agriculture, Eur. J. Agron., 19, 135160, 2003.

Heuvelink, G. B. M.: Error propagation in environmental modelling with GIS, Taylor \& Francis, London, 127 pp., 1998.

Heuvelink, G. B. M. and Pebesma, E. J.: Spatial aggregation and soil process modelling, Geoderma, 89, 47-65, 1999.

IPCC: IPCC Guidelines for National Greenhouse Gas Inventories, Prepared by the National Greenhouse Gas Inventories Programme, edited by: Eggleston, H. S., Buendia, L., Miwa, K., Ngara, T., and Tanabe, K., IGES, Japan, 2006.

Jansen, M. J. W., Schouwenberg, E. P. A. G., Mol-Dijkstra, J. P., Kros, J., and Houweling, H.: Variance-based regression-free uncertainty analysis for groups of inputs applied to a model chain in nature conservation, in: Foresight and Precaution, edited by: Cottam, M. P., Harvey, D. W., Pape, R. P., and Tait, J., Balkema, Rotterdam, 1127-1131, 2000.

Keuskamp, J., van Drecht, G., and Bouwman, A. F.: European scale modelling of groundwater denitrification and associated $\mathrm{N}_{2} \mathrm{O}$ production, Environ. Pollut., 165C, 67-76, doi:10.1016/j.envpol.2012.02.008, 2012.

Klaassen, G., Amann, M., Berglund, C., Cofala, J., HöglundIsaksson, L., Heyes, C., Mechler, R., Tohka, A., Schöpp, W., and Winiwarter, W.: The Extension of the RAINS Model to Greenhouse Gases, International Institute for Applied Systems AnalysisInterim Report IR-04-015, 136, 2004.

Klimont, Z. and Brink, C.: Modelling of emissions of air pollutants and greenhouse gases from agricultural sources in Europe, International Institute for Applied Systems AnalysisInterim Report IR-04-048, 75, 2004.

Kros, J., Frumau, K. F. A., Hensen, A., and De Vries, W.: Integrated analysis of the effects of agricultural management on nitrogen fluxes at landscape scale, Environ. Pollut., 159, 31713182, 2011.

Lehuger, S., Gabrielle, B., van Oijen, M., Makowski, D., Germon, J.-C., Morvan, T., and Hénault, C.: Bayesian calibration of the nitrous oxide emission module of an agroecosystem model, Agr. Ecosyst. Environ., 133, 208-222, doi:10.1016/j.agee.2009.04.022, 2009.

Leip, A.: Gap analysis of the Activity Data for the calculation of European Greenhouse Gas Emissions from Agriculture, Internal paper addressed to services of the European Commission, 2004.

Leip, A.: Quantitative quality assessment of the greenhouse gas inventory for agriculture in Europe, Climatic Change, 103, 245261, doi:10.1007/s10584-010-9915-5, 2010.

Leip, A., Marchi, G., Koeble, R., Kempen, M., Britz, W., and $\mathrm{Li}, \mathrm{C}$.: Linking an economic model for European agriculture with a mechanistic model to estimate nitrogen and carbon losses from arable soils in Europe, Biogeosciences, 5, 73-94, doi:10.5194/bg-5-73-2008, 2008.

Leip, A., Achermann, B., Billen, G., Bleeker, A., Bouwman, A. F., de Vries, W., Dragosits, U., Döring, U., Fernall, D., Geupel, M., Johnes, P., Le Gall, A. C., Monni, S., Neveèeøal, R., Orlandini, L., Prud'homme, M., Reuter, H. I., Simpson, D., Seufert, G.,
Spranger, T., Sutton, M. A., van Aardenne, J., Voß, M., and Winiwarter, W.: Integrating nitrogen fluxes at the European scale, in: The European Nitrogen Assessment, edited by: Sutton, M. A., Howard, C. M., Erisman, J. W., Billen, G., Bleeker, A., Grennfelt, P., van Grinsven, H., and Grizzetti, B., Cambridge University Press, Chapter 16, Cambridge, UK, 345-376, 2011 a.

Leip, A., Busto, M., Corazza, M., Bergamaschi, P., Koeble, R., Dechow, R., Monni, S., and de Vries, W.: Estimation of $\mathrm{N}_{2} \mathrm{O}$ fluxes at the regional scale: data, models, challenges, Current Opinion in Environmental Sustainability, 3, 328-338, 2011 b.

Lesschen, J. P., Stoorvogel, J. J., Smaling, E. M. A., Heuvelink, G. B. M., and Veldkamp, A.: A spatially explicit methodology to quantify soil nutrient balances and their uncertainties at the national level, Nutr. Cycl. Agroecosyst., 78, 111-131, doi:10.1007/s10705-006-9078-y, 2007.

Lesschen, J. P., Velthof, G. L., de Vries, W., and Kros, J.: Differentiation of nitrous oxide emission factors for agricultural soils, Environ. Pollut., 159, 3215-3222, doi:10.1016/j.envpol.2011.04.001, 2011.

Limpert, E., Stahel, W. A., and Abbt, M.: Log-normal distributions across the sciences: Keys and clues, BioScience, 51, 341-352, 2001.

Mosier, A., Kroeze, C., Nevison, C., Oenema, O., Seitzinger, S., and van Cleemput, O.: Closing the global $\mathrm{N}_{2} \mathrm{O}$ budget: nitrous oxide emissions through the agricultural nitrogen cycle (OECD/IPCC/IEA phase II development of IPCC guidelines for national greenhouse gas inventory methodology), Nutr. Cycl. Agroecosyst., 52, 225-248, 1998.

Nol, L., Heuvelink, G. B. M., Veldkamp, A., de Vries, W., and Kros, J.: Uncertainty propagation analysis of an $\mathrm{N}_{2} \mathrm{O}$ emission model at the plot and landscape scale, Geoderma, 159, 9-23, doi:10.1016/j.geoderma.2010.06.009, 2010.

Oenema, O., Kros, H., and de Vries, W.: Approaches and uncertainties in nutrient budgets: implications for nutrient management and environmental policies, Eur. J. Agron., 20, 3-16, 2003.

Pihlatie, M., Syvasalo, E., Simojoki, A., Esala, M., and Regina, K.: Contribution of nitrification and denitrification to $\mathrm{N}_{2} \mathrm{O}$ production in peat, clay and loamy sand soils under different soil moisture conditions, Nutr. Cycl. Agroecosyst., 70, 135-141, 2004.

Refsgaard, J. C., van der Sluijs, J. P., Brown, J., and van der Keur, P.: A framework for dealing with uncertainty due to model structure error, Adv Water Resour., 29, 1586-1597, doi:10.1016/j.advwatres.2005.11.013, 2006.

Saltelli, A., Tarantola, S., Campolongo, F., and Ratto, M.: Sensitivity Analysis in Practice, A Guide to Assessing Scientific Models, Wiley, New York, 2004.

Schulze, E. D., Luyssaert, S., Ciais, P., Freibauer, A., Janssens, I. A., Soussana, J. F., Smith, P., Grace, J., Levin, I., Thiruchittampalam, B., Heimann, M., Dolman, A. J., Valentini, R., Bousquet, P., Peylin, P., Peters, W., Rödenbeck, C., Etiope, G., Vuichard, N., Wattenbach, M., Nabuurs, G. J., Poussi, Z., Nieschulze, J., and Gash, J. H.: Importance of methane and nitrous oxide for Europe's terrestrial greenhouse-gas balance, Nat. Geosci., 2, 842850, doi:10.1038/ngeo686, 2009.

Simpson, D., Butterbach-Bahl, K., Fagerli, H., Kesik, M., Skiba, U., and Tang, S.: Deposition and emissions of reactive nitrogen over European forests: A modelling study, Atmos. Environ., 40, 5712-5726, doi:10.1016/j.atmosenv.2006.04.063, 2006. 
Stehfest, E. and Bouwman, L.: $\mathrm{N}_{2} \mathrm{O}$ and $\mathrm{NO}$ emission from agricultural fields and soils under natural vegetation: summarizing available measurement data and modeling of global annual emissions, Nutr. Cycl. Agroecosyst., 74, 207-228, 2006.

Stohl, A., Williams, E., Wotawa, G., and Kromp-Kolb, H.: A European inventory of soil nitric oxide emissions and the effect of these emissions on the photochemical formation of ozone, Atmos. Environ., 30, 3741-3755, doi:10.1016/13522310(96)00104-5, 1996.

Sutton, M. A., Nemitz, E., Erisman, J. W., Beier, C., ButterbachBahl, K., Cellier, P., de Vries, W., Cotrufo, F., Skiba, U., Di Marco, C., Jones, S., Laville, P., Soussana, J. F., Loubet, B., Twigg, M., Famulari, D., Whitehead, J., Gallagher, M. W., Neftel, A., Flechard, C. R., Herrmann, B., Calanca, P. L., Schjoerring, J. K., Daemmgen, U., Horvath, L., Tang, Y. S., Emmett, B. A., Tietema, A., Peñuelas, J., Kesik, M., Brueggemann, N., Pilegaard, K., Vesala, T., Campbell, C. L., Olesen, J. E., Dragosits, U., Theobald, M. R., Levy, P., Mobbs, D. C., Milne, R., Viovy, N., Vuichard, N., Smith, J. U., Smith, P., Bergamaschi, P., Fowler, D., and Reis, S.: Challenges in quantifying biosphereatmosphere exchange of nitrogen species, Environ. Pollut., 150, 125-139, doi:10.1016/j.envpol.2007.04.014, 2007. van der Sluijs, J. P.: Uncertainty and precaution in environmental management: Insights from the UPEM conference, Environ. Modell. Softw., 22, 590-598, 2007.

Van Drecht, G., Bouwman, A. F., Knoop, J. M., Beusen, A. H. W., and Meinardi, C. R.: Global modeling of the fate of nitrogen from point and nonpoint sources in soils, groundwater, and surface water, Global Biogeochem. Cy., 17, 1115, doi:10.1029/2003GB002060, 2003.

Van Gijlswijk, R., Coenen, P., Pulles, T., and van der Sluijs, J.: Uncertainty assessment of $\mathrm{NO}_{\mathrm{x}}, \mathrm{SO}_{2}$ and $\mathrm{NH}_{3}$ emission in the Netherlands, TNO Environment Energy and Process Inovation, ApeldoornR 2004/100, 102 pp., 2004.

Velthof, G. L., Oudendag, D. A., Witzke, H. P., Asman, W. A. H., Klimont, Z., and Oenema, O.: Integrated assessment of nitrogen emission losses from agriculture in EU27 using MITERRA-EUROPE, J. Environ. Qual., 38, 1-16, doi:10.2134/jeq2008.0108, 2009. 